\title{
On the Causes and Consequences of Recent Trends in Atmospheric Methane
}

\author{
Hinrich Schaefer ${ }^{1}$ (D) \\ Published online: 22 August 2019 \\ (C) The Author(s) 2019
}

\begin{abstract}
Purpose of Review To investigate which processes cause the current increase in atmospheric methane in the context of future interactions between climate change, the methane cycle and policy decisions.

Recent Findings There is evidence for various contributors to emission increases or reduced removal of atmospheric methane. No single process can explain the methane rise and remain consistent with available data. Reconstructions of recent changes in the methane budget do not converge as to the dominant contributor to the rise. A plausible scenario includes increasing emissions from agriculture and fossil fuels while biomass burning is reduced, with possible contributions from wetlands and a weakened sink.

Summary Further studies are needed to identify contributors to the methane rise for targeted emission reductions and adaptation to changes in natural methane sources and sinks. Mitigation plans must address the methane rise and possible consequences from a climate-methane feedback.
\end{abstract}

Keywords Methane $\cdot \mathrm{CH}_{4} \cdot$ Climate change $\cdot$ Isotopes $\cdot$ Radiative forcing $\cdot$ Climate policy

\section{Introduction}

Atmospheric levels of methane (measured as mole fraction $\left[\mathrm{CH}_{4}\right]$ in dry air), have increased throughout the industrial period $[1 \bullet \bullet$. This is due to anthropogenic emissions from agriculture (ruminant livestock and rice farming), fossil fuel use and waste management, associated with population growth. $\left[\mathrm{CH}_{4}\right]$ growth slowed in the 1990 s and plateaued from 1999 to 2006 but resumed in 2007 (hereafter referred to as the renewed rise) and accelerated in $2014[2 \bullet \bullet, 3 \bullet \bullet]$ (Fig. 1). Understanding the changes underlying these $\left[\mathrm{CH}_{4}\right]$ trends can identify sources or sinks that respond to environmental, land use or economic changes. This is necessary to mitigate anthropogenic climate change through targeted emission reductions. Any cuts will lower $\left[\mathrm{CH}_{4}\right]$; but for agriculture and

This article is part of the Topical Collection on Carbon Cycle and Climate

Hinrich Schaefer

Hinrich.Schaefer@niwa.co.nz

1 National Institute of Water and Atmospheric Research, 301 Evans Bay Parade, Wellington 6021, New Zealand fossil fuels as the main anthropogenic sources, decisions must balance emission cuts with the necessities of food and energy supplies. Successful climate policy must identify possible feedbacks between anthropogenic climate change and sources like wetlands, which may increase due to warming and precipitation shifts.

Bottom-up (BU) studies reconstruct changes from economic data or environmental observations, often employing process models and constraining environmental data. BU estimates are source specific but limited by problems in process understanding and upscaling, when global levels are derived from limited and variable field measurements without constraints on the total. Top-down (TD) studies use atmospheric observations of $\left[\mathrm{CH}_{4}\right]$ and other parameters to quantify source and sink fluxes in atmospheric models. They constrain cumulative changes but provide limited understanding of individual processes. They are subject to uncertainty and bias in the constraining observations and first-guess (a priori) data sets and are underconstrained (e.g. emission reconstructions are affected by simultaneous sink changes without sufficient observations to quantify both). Important observational constraints are as follows: (i) temporal and geographic $\left[\mathrm{CH}_{4}\right]$ variabilities measured in surface observations and by 


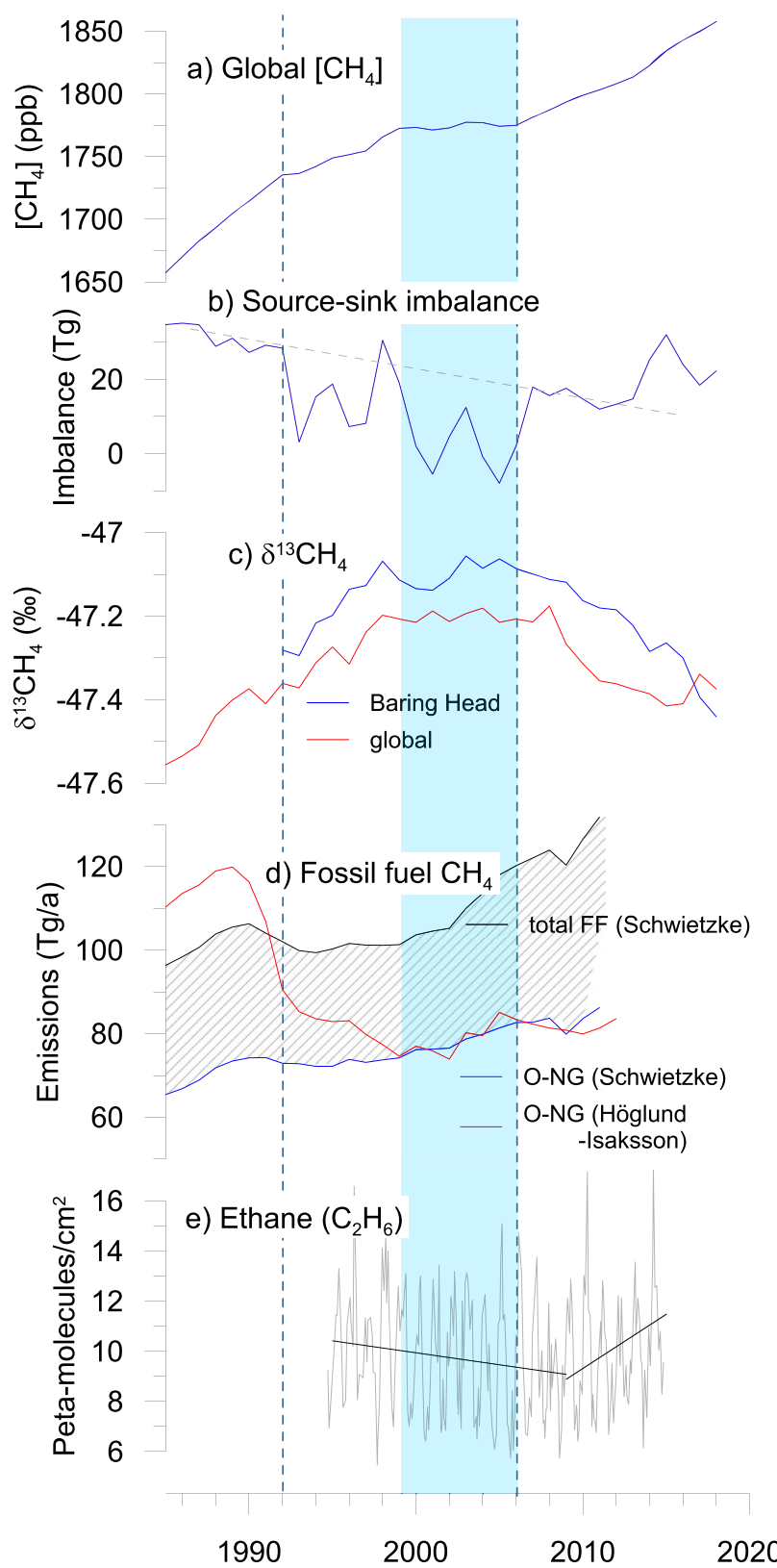

Fig. 1 Trends in atmospheric methane, its sources and main sink. a Global mole fraction of $\mathrm{CH}_{4}$ from NOAA-ESRL [3••]; b source-sink imbalance derived from the $\left[\mathrm{CH}_{4}\right]$ growth rate; $\mathbf{c} \delta^{13} \mathrm{CH}_{4}$ records from Baring Head, New Zealand, and global average [4]; d global BU fossil fuel $\mathrm{CH}_{4}$ emissions from oil and natural gas production $(\mathrm{O}-\mathrm{NG})[5,6]$ and total values, hatched area indicates emissions from coal mining [5]; $\mathbf{e}$ ethane total column observations and trends from Jungfraujoch, Switzerland [7]; f global yearly [8] and decadal [9] BU estimates of $\mathrm{CH}_{4}$ emissions from ruminant livestock; $g$ global BU estimates of biomass burning $\mathrm{CH}_{4}$ emissions $[10,11 \bullet \bullet, 12]$; $\mathbf{h}$ global multi-model wetland

satellites; (ii) the isotopic signature of methane, mostly its stable carbon isotope ratio $\left({ }^{13} \mathrm{C} /{ }^{12} \mathrm{C}\right.$; expressed as $\delta^{13} \mathrm{CH}_{4}$ relative to the $\mathrm{PDB}$ standard in per mille), which indicates varying activities of source and sink types; (iii) proxies undergoing the same processes as methane, e.g. ethane $\left(\mathrm{C}_{2} \mathrm{H}_{6}\right)$ is coemitted from fossil fuel sources, and methyl chloroform

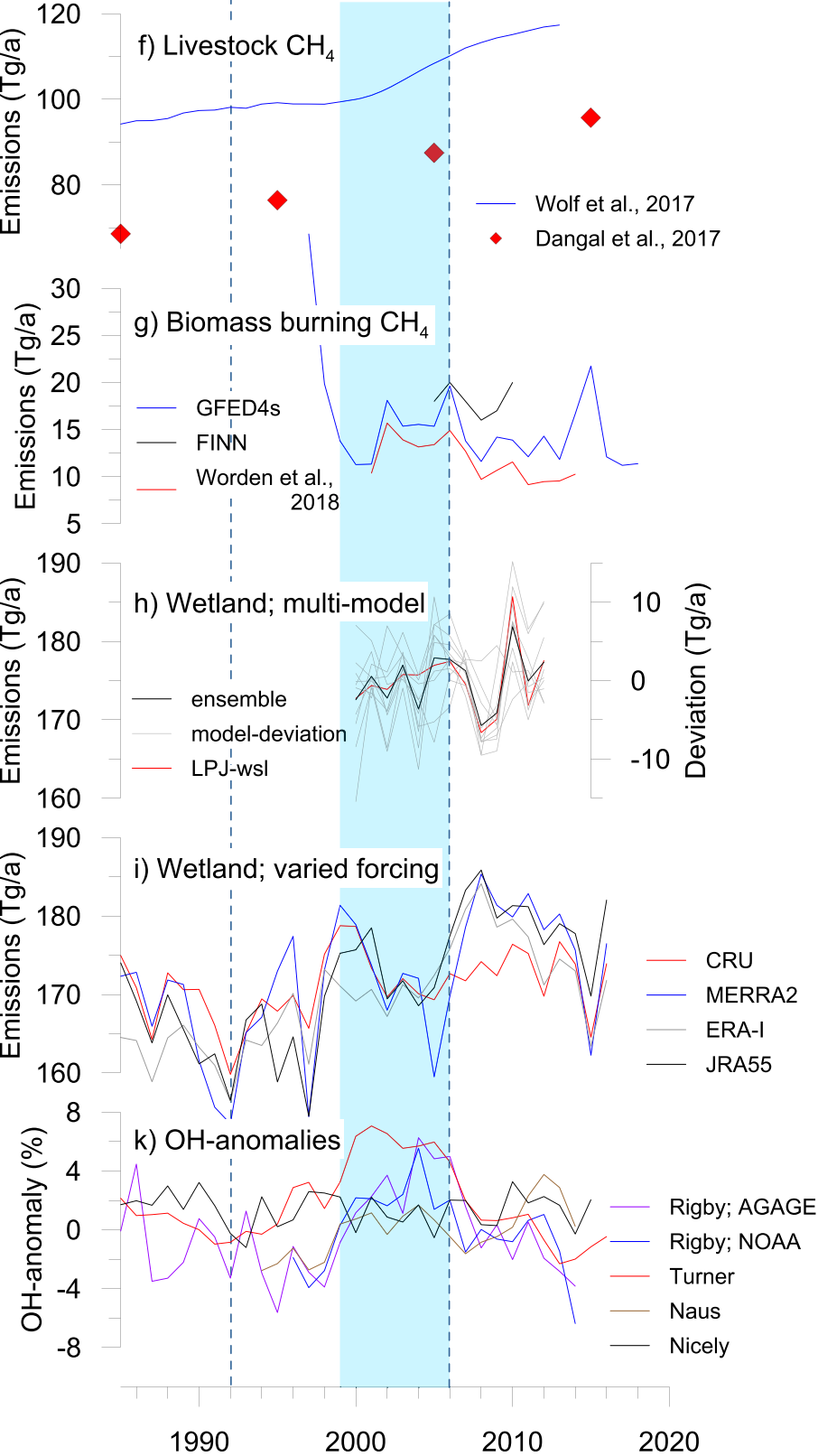

$\mathrm{CH}_{4}$ emissions for identical forcing [13•], individual model runs are shown as anomalies relative to the ensemble average over the study period; i global wetland $\mathrm{CH}_{4}$ emissions modelled for different climate reconstructions [14•] (red lines in panels $\mathbf{h}$ and $\mathbf{i}$ indicate results for the same model and climate data set); $\mathbf{k}$ global $\mathrm{OH}$ anomalies as reconstructed using MCF records from AGAGE and NOAA [15•, 16, 17] and from an atmospheric process model [18], anomalies are reported relative to varying reference periods. Vertical blue dashed lines indicate the start and end of the source-sink imbalance anomaly. Blue shading indicates the $\left[\mathrm{CH}_{4}\right]$ plateau

(MCF) is removed from the atmosphere by the dominant $\mathrm{CH}_{4}$ sink (destruction through the hydroxyl radical $(\mathrm{OH})$ ); (iv) climate, economic and environmental data that inform $\mathrm{BU}$ inventories and process models. All reconstructions of the methane history are fundamentally underconstrained by observations, due to the multitude of sources and sinks. 
Strategies to address these issues are summarised by [19॰]. To date, there is no consensus on what caused the renewed rise.

This review will summarise recent assessments of (i) the total methane budget; (ii) climate forcing of methane and implications for policy; (iii) the relationship between climate and the natural methane cycle as observed in old air from ice and firn (perennial snow); (iv) the expected response of the methane cycle in a changing environment; (v) the methane budget changes leading to the $\left[\mathrm{CH}_{4}\right]$ plateau and renewed rise. The goal is to assess consistencies and contradictions between different reconstructions of the methane cycle and test them against the cumulative evidence of observations.

\section{The Total Methane Budget: Reconciling Bottom-up and Top-down Estimates}

The Global Carbon Project (GCP) quantified the global methane budget through combined BU (emission inventories and process models) and TD estimates such as model inversions of atmospheric observations [20•0]. Globally, published best estimates for individual BU sources differ by less than $\pm 25 \%$ (note that combined uncertainty is higher than this envelope); TD estimates are generally lower but fall within that range $[20 \bullet$. Only natural sources except wetlands (e.g. freshwater, geologic and oceanic sources, wild animals) have $\geq 50 \%$ BU best estimate ranges and strongly exceed TD estimates. This is the main cause of the discrepancy between total BU ( $740 \mathrm{Tg} / \mathrm{a})$ and TD $(\sim 560 \mathrm{Tg} / \mathrm{a})$ source estimates [20••]. The GCP distinguishes more subcategories of sources and recognises new emission types than earlier budgets as summarised in [21], e.g. freshwater emissions are separate from wetlands. Not yet included are probably minor emissions from glacial systems (other than permafrost soils) [22], terrestrial aquaculture [23] and breakdown of plastics in the environment [24]. In the GCP TD budget, at least half of the emissions are anthropogenic: $\sim 34 \%$ (BU 26\%) of total from agriculture, $19 \%$ (BU 16\%) from fossil fuels, plus contributions from biomass and biofuel burning. Natural wetlands contribute $\sim 30 \%$ (BU 25\%) [20••]. Emissions are concentrated in the tropics $(64 \%)$ and northern mid-latitudes (32\%) [20••]. Fossil fuel emissions are $8 \%$ lower than in older budgets [21]; other source percentages changed less. Recent studies revise anthropogenic fossil fuels upwards again, based on evidence from $\delta^{13} \mathrm{CH}_{4}\left[25^{\circ}\right]$ and ethane/propane ratios [26]. A strong downward revision of the geologic source (natural emissions from fossil fuel deposits) based on the preindustrial methane radiocarbon content [27] to $<16 \mathrm{Tg} / \mathrm{a}$ would also suggest a higher industrial fossil fuel component. Such low geologic emission estimates challenge threefold higher inventory [28] and $\delta^{13} \mathrm{CH}_{4}$-based [25•] estimates of this source.

\section{Radiative Forcing of Methane and Policy Implications}

Methane's strong radiative forcing (RF) and short atmospheric residence time ( $\sim 9$ years) combine to a high global warming potential over 100 years $\left(\mathrm{GWP}_{100}\right.$, climate impact relative to carbon dioxide). A GWP ${ }_{100}$ value of 28 , presented by the IPCC [29], is commonly used in the comparison of various greenhouse gases (GHGs). Additional indirect forcing from aerosol interactions and methane's climate active decay products bring its $\mathrm{GWP}_{100}$ to $\sim 33$ [30]. Water vapour effects on stratospheric ozone $(+15 \%$ of direct RF [31]) and shortwave RF $(+15 \%$ of total RF [32••] with regionally stronger forcing [33]) increase methane's $\mathrm{GWP}_{100}$ even further. Locally, decreasing water vapour trends lead to reduced spectral overlap with $\mathrm{CH}_{4}$ and similar surface forcings for $\mathrm{CO}_{2}$ and $\mathrm{CH}_{4}$ [34]. Stronger RF increases the importance of $\mathrm{CH}_{4}$ emission reductions. Methane forcing impacts ocean heat content and associated sea level rise beyond its residence time [35]. Nevertheless, as a short-lived climate pollutant (SLCP), stable and falling $\mathrm{CH}_{4}$ emissions lead to a halt of atmospheric warming and to cooling, respectively, while any non-zero emissions of cumulative climate pollutants (CCPs) like $\mathrm{CO}_{2}$ cause further warming [36 $]$. Compared to reducing $\mathrm{CCPs}$, the priority of $\mathrm{CH}_{4}$ cuts depends on the climate policy target. Methane emissions must only be stabilised before a given peak temperature is reached, but earlier cuts mitigate climate feedbacks and avoid climate tipping points. Methane mitigation is therefore of higher importance for the Representative Concentration Pathways (RCPs) that target a lower global temperature increase, such as RCP-2.6. Even under the most optimistic scenarios for future political and economic developments, as exemplified by the Shared Socioeconomic Pathway 1 (SSP1), methane cuts have to be regulated through policies [37]. The SSP1 scenario allows for a low level of SLCPs by 2100, while CCPs must be zero or negative [37]. Lowering $\left[\mathrm{CH}_{4}\right]$ is an alternative to atmospheric $\mathrm{CO}_{2}$ removal [36•], which looks to be necessary for the Paris climate goals. Cutting $\mathrm{CH}_{4}$ emissions would demand stronger efforts from sectors like agriculture and waste and from different countries than for CCP reductions [38]. Given that current emission pathways demand falling $\left[\mathrm{CH}_{4}\right]$ [39], the renewed rise requires even stronger $\mathrm{CH}_{4}$ emission cuts or compensating reductions of other GHGs [2••]. Emissions can be reduced by environmental regulations, as have been enacted for fugitive emissions in China [40] and the USA [41]. The reduction potential for $\mathrm{CH}_{4}$ emissions depends on technical feasibility, consumer choices, and economic costs of the cuts weighed against a given carbon price. Agricultural non- $\mathrm{CO}_{2}$ emissions (incl. $\mathrm{CH}_{4}$ ) could be mitigated by $\sim 50 \%$ in 2050 at carbon prices compatible with the $1.5{ }^{\circ} \mathrm{C}$ goal $\left(\sim 950 \mathrm{USD} / \mathrm{t} \mathrm{CO}_{2}\right.$-equivalent), but only by $15 \%$ at $\$ 20 \mathrm{USD} / \mathrm{t} \mathrm{CO}_{2}$-equivalent [42]. The maximum reduction potential for all anthropogenic $\mathrm{CH}_{4}$ sources by 2050 is $\sim 51 \%$, most of which ( $40 \%$ reduction) 
is achieved at carbon prices below $\$ 500 \mathrm{USD} / \mathrm{t} \mathrm{CO}_{2}$-equivalent [43]. A potential $\left[\mathrm{CH}_{4}\right]$ rise from natural emissions or weakened sinks that cannot be mitigated would strongly challenge climate policies. For example, modelled wetlands and permafrost emissions due to anthropogenic climate change in 2100 reduce the fossil fuel budget to keep below $1.5{ }^{\circ} \mathrm{C}$ by $9-15 \%$ under SSP2-RCP2.6 [44]; SSP-RCP pathways that lead to higher radiative forcing [45] will exacerbate the problem.

\section{Past Methane Cycle Changes: Possible Indicators of Future Trends}

Ice core records show that throughout the glacial period, fast $\left[\mathrm{CH}_{4}\right]$ increases followed warming of the northern hemisphere [46]. Reconstructing the underlying processes, while acknowledging differences in base climate and nature of the warming, constrains future responses of natural $\mathrm{CH}_{4}$ to climate.

Hydroxyl changes had minor influence on past $\left[\mathrm{CH}_{4}\right]$ according to atmospheric chemistry-climate models (ACCMs). Both for glacial-interglacial (G-IG) differences and millennial-scale climate fluctuations, insignificant $\mathrm{OH}$ shifts resulted from cumulative changes in humidity, temperature and fluxes of $\mathrm{OH}$ precursors and reactants [47, 48]. Differences in base climate limit an extrapolation of these results for future warming. An ACCM simulation of the last interglacial period (LIG, $\sim 120,000$ years ago) suggests a $10 \%$ increase in $\mathrm{OH}$ removal for conditions $\sim 2{ }^{\circ} \mathrm{C}$ warmer than the preindustrial Holocene (PIH) [49]. Ice core proxies suggest $\leq 50 \%$ G-IG difference (with large uncertainties), implying that $\mathrm{ACCMs}$ underestimate past $\mathrm{OH}$ changes [50].

Strong $\mathrm{CH}_{4}$ emissions from destabilised $\mathrm{CH}_{4}$ or organic carbon reservoirs, like methane hydrates or permafrost, are the biggest concern for climate feedbacks. Ice core measurements of the $\mathrm{CH}_{4}$ isotope systems $\left(\delta^{13} \mathrm{CH}_{4}, \delta \mathrm{D}-\mathrm{CH}_{4}\right.$ and radiocarbon) indicate that such reservoirs made at most minor contributions to $\left[\mathrm{CH}_{4}\right]$ increases on different timescales (e.g. $[27,51])$. Evidence from isotopes, climate records [52] and the interpolar $\left[\mathrm{CH}_{4}\right]$ difference (IPD, constraining the relative contributions from tropical and boreal wetlands [46]) shows that tropical and temperate wetlands control past $\left[\mathrm{CH}_{4}\right]$ on centennial and millennial scales and G-IG transitions [46, $52,53]$, including $\left[\mathrm{CH}_{4}\right]$ increases not associated with Greenland warming [54]. Boreal emissions increased across warming events but mainly after temperature and $\left[\mathrm{CH}_{4}\right]$ had levelled out [46]. During the LIG, wetland models suggest higher emissions than today [49], within large uncertainties regarding past wetland extent and model skill [13•]. Charcoal records indicate reduced biomass burning under full glacial conditions [55], which may have contributed to the GIG $\left[\mathrm{CH}_{4}\right]$ difference [47] and shorter term $\left[\mathrm{CH}_{4}\right]$ variability [52].
In summary, past natural $\left[\mathrm{CH}_{4}\right]$ changes triggered by climate seem to be driven by tropical wetlands while boreal wetlands, clathrates, permafrost and $\mathrm{OH}$ changed either little or gradually.

\section{Potential Future Feedbacks Between Climate and the Methane Cycle}

Future $\mathrm{CH}_{4}$-climate feedbacks, i.e. increasing natural emissions in response to climate change, have recently been reviewed [56•]. Marine hydrates store huge volumes of $\mathrm{CH}_{4}$ and are vulnerable to destabilisation by ocean warming and sea level change. However, modelling hydrate dissociation in response to climate change shows that deposits are either too small or insensitive to external forcing to cause significant $\left[\mathrm{CH}_{4}\right]$ feedback [57]. The large potential for $\mathrm{CH}_{4}$ oxidation in overlying sediments and seawater prevents release to the atmosphere [58]. Boreal permafrost could release stored carbon as $\mathrm{CH}_{4}$ under disproportionately strong warming and precipitation increase. Estimates of this source (incl. on-shore hydrates) in climate trajectories for business-as-usual (e.g. RCP-8.5) GHG pathways are 39-57 Tg/a by 2100 and $\leq$ $130 \mathrm{Tg} / \mathrm{a}$ by $2300\left[56^{\bullet}\right]$. The permafrost-carbon feedback for RCP-8.5 increases from $\sim 0.3{ }^{\circ} \mathrm{C}$ warming (with $20 \% \mathrm{CH}_{4}$ contribution) by 2100 for gradual permafrost thaw to $0.5{ }^{\circ} \mathrm{C}$ (with $70 \% \mathrm{CH}_{4}$ contribution) if abrupt thaw is considered [59]. Expected wetland $\mathrm{CH}_{4}$ emissions increase $\sim 50 \mathrm{Tg} / \mathrm{a}$ or $\sim 130-160 \mathrm{Tg} / \mathrm{a}$ by 2100 under RCP2.6 [60] and RCP8.5, respectively $[56 \cdot, 60]$, due to carbon fertilisation. Future forcings from precipitation and temperature are thought to be minor and opposing each other. Such projections carry large uncertainties due to limited process understanding of wetland and permafrost emissions [13•]. Estimates for a combined $\mathrm{CH}_{4}$-climate feedback of $\sim 180 \mathrm{Tg} / \mathrm{a}$ from wetlands and permafrost [56 $]$ exceed present-day fossil fuel $\mathrm{CH}_{4}$ emissions ( $110 \mathrm{Tg} / \mathrm{a})$ and are similar to current agricultural emissions [20••]. GHG cuts exceeding all industrial $\mathrm{CH}_{4}$ sources will be required to compensate for additional natural $\mathrm{CH}_{4}$ emissions.

Future changes in the $\mathrm{OH}$ sink depend strongly on emissions of $\mathrm{CH}_{4}$ as well as of $\mathrm{OH}$ precursors and sinks like $\mathrm{CO}$ and $\mathrm{NO}_{x}$. At moderate $\left[\mathrm{CH}_{4}\right]$ changes, the interplay of climate and chemistry impacts keep $\mathrm{OH}$ comparably steady. Strong $\mathrm{CH}_{4}$ increases will extend its atmospheric residence time by $10 \%[61]$ and exacerbate its climate impact.

\section{Causes of the Recent Trend Changes in $\left[\mathrm{CH}_{4}\right]$}

The distinct onset of the renewed rise constitutes a scientific opportunity and political necessity to identify processes that are currently increasing $\left[\mathrm{CH}_{4}\right]$. The renewed rise may be 
either an anomaly when a new emissions-sinks configuration emerged or the end of an anomalous plateau period during which $\left[\mathrm{CH}_{4}\right]$ growth was suppressed [19•]. The short duration of the plateau ( 7 years vs renewed growth of 12 years to date) and the similarity in $\left[\mathrm{CH}_{4}\right]$ growth rate before and after [19•] support an anomalous plateau, e.g. the temporary decrease of $\mathrm{a} \mathrm{CH}_{4}$ source. Also, the source-sink imbalance follows similar trends before and after the plateau but shows high interannual variability (IAV) and depressed emissions over removal between 1993 and 2006 (Fig. 1b). In contrast, the assumption that the renewed rise constitutes the anomaly is consistent with opposing $\delta^{13} \mathrm{CH}_{4}$ trends before and after the plateau [62 •] (Fig. 1c), indicating that the balance between individual sources and sinks shifted fundamentally between the preplateau $\left[\mathrm{CH}_{4}\right]$ growth and the renewed rise. If the plateau resulted from steady state between sources and sinks, anthropogenic emissions must have decoupled from population and economic growth (unless balanced by decreasing natural emissions). Possible explanations are advances in technology and management practices in the energy and waste sectors, as well as rice agriculture. However, it is unclear what regulatory and economic pressure would have forced anthropogenic emission reductions in the 1990s.

Economic changes like growing agriculture or an upswing in Asian industrial activity could have caused the renewed rise. Possibly, climate patterns changed, like higher rates of global temperature change or a switch between predominant El Niño Southern Oscillation (ENSO) phases with regional precipitation and temperature shifts [63]. Estimated increases for individual sources, in addition to hypothesised weakening of the sink, exceed in combination the source-sink imbalance of the renewed rise (Fig. 2b). Therefore, the problem is the identification of overestimated changes and the quantification of the actual drivers of the renewed rise. The following sections review evidence for source changes controlled by economy or climate and large enough to affect the renewed rise. Note that comparison periods (plateau vs renewed rise) vary between different quoted studies. This precludes an exact comparison of the various estimates but allows for the identification of patterns. All comparison periods are listed in Fig. 2 and Table 1.

\section{Possible Source and Sink Changes as Cause of the Renewed Rise}

\section{Agriculture}

Agriculture is the largest anthropogenic $\mathrm{CH}_{4}$ source, dominated by ruminant livestock and a smaller contribution from rice paddies. Herd numbers and emissions from rice fields can be impacted by climate events (e.g., droughts) or economic factors (e.g., changing demand). Emission intensity may change with farming techniques [70] and animal diet [9], although this likely occurs more gradually than the marked trend changes observed in $\left[\mathrm{CH}_{4}\right]$.

Reconstructions of ruminant emissions, based on ruminant populations and energy intake (type and mass of feed), find an increase between plateau and renewed rise of $8 \mathrm{Tg} / \mathrm{a}(2000$ 2009 vs 2010-2015) [9] and $12 \mathrm{Tg} / \mathrm{a}$ (2003 vs 2010) [8] (Figs. 1f, 2b). Decadal reconstructions show higher growth into the plateau period ( $14 \%$ between the 1990 s and 2000 s) than in the decades before and after $(11 \%$ between the $1980 \mathrm{~s}$ and 1990s; 9\% between 2000s and 2010-2015) [9]. Yearly reconstructions show increasing growth starting around 2002, the magnitude of which may be underestimated due to poorer preceding data [8]. A dip in emissions in the 1990s is not evident, possibly for the same reason. India hosts the world's largest ruminant population and $\sim 20 \%$ of global rice production. Agricultural data from India show a 3\% decrease in livestock numbers between 2006 and 2014 and TD emissions for all sources in India between 2010 and 2015 remained constant [76]; agricultural emissions do not seem to be currently increasing in this key region. Rice-growing area in the major production regions decreased $\sim 4 \%$ between 2000 and 2015 [77]. The resulting change in $\mathrm{CH}_{4}$ emissions will be affected by concurrent changes in farming practice [70]. A biogeochemical model of rice emissions informed by satellite estimates of inundation area shows that the exponential rise in rice emissions throughout the 1900s stagnated in the 2000s and dropped in the first 2 years of the renewed increase [70] (Fig. $2 b)$. Inventories suggest that rice emissions have recovered and are now increasing but their role in the renewed rise is likely modest [64••], whereas ruminant emissions are likely contributors to the renewed rise $[8,9,64 \bullet \bullet]$.

\section{Fossil Fuel Emissions}

Fugitive $\mathrm{CH}_{4}$ from fossil fuel production infrastructure like oil and natural gas $(\mathrm{O}-\mathrm{NG})$ wells is co-emitted with ethane. A northern hemispheric ethane decline reversed to a rise around 2007 (Fig. 1e), coincident with the renewed rise and a global increase in gas wells. These trends seem to suggest that $\mathrm{CH}_{4}$ emissions gradually increased between 2006 and 2014 by 15 to $>20 \mathrm{Tg} / \mathrm{a}$, commonly attributed to unconventional gas production [7, 71] (Fig. 2b). These results have been questioned, due to assumed constant $\mathrm{C}_{2} \mathrm{H}_{6} / \mathrm{CH}_{4}$ ratios and enrichment factors. $\mathrm{C}_{2} \mathrm{H}_{6} / \mathrm{CH}_{4}$ ratios may have increased with more gas production from oil fields [78] (although this is not evident in fossil fuel inventories [5, 65]). Enrichment factors change in time and space so that ethane and $\mathrm{CH}_{4}$ may trend independently; in the USA, $\left[\mathrm{CH}_{4}\right]$ shows no significantly higher increase in fossil fuel production regions than elsewhere [79•]. BU emissions from $\mathrm{O}-\mathrm{NG}$ production increase $\sim 5 \mathrm{Tg}$ /a between plateau (1999-2006) and renewed rise (2007-2011 [6]; or 2007-2012 [5]), associated with unconventional gas production since 2005 (Figs. 1d, 2b). The BU trends depend strongly on the 


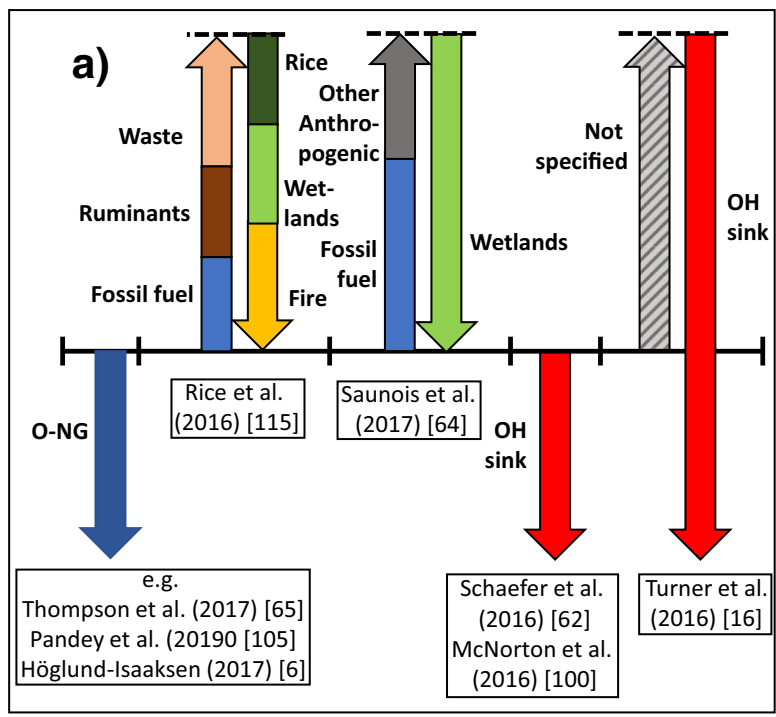

Fig. 2 Scenarios for plateau onset and renewed rise. a Explanations for the onset of the $\left[\mathrm{CH}_{4}\right]$ plateau shown as qualitative scenarios according to the references given in the figure. $\mathbf{b}$ Estimates of changes in emissions, total source-sink imbalance and removal by $\mathrm{OH}$ between the plateau period and the renewed rise. Estimates are for global totals (solid fill) unless otherwise specified; estimates for specific regions shown in hatched bars. O-NG, coal gas and wetlands are plotted to scale on offset $y$-axes to illustrate the cumulative estimates over multiple source types. Total source-sink balance estimates are from whole-budget models (see Table 1 for details). Positive values for the $\mathrm{OH}$ sink indicate $\left[\mathrm{CH}_{4}\right]$ increase due to weakened removal. Individual estimates (from left to right) are the following. Rice: [70], $-3 \mathrm{Tg} / \mathrm{a}$ (2004 vs 2007, process model). Fire: Ref [10], - $1.3 \mathrm{Tg} / \mathrm{a}$ (1999-2006 vs 2007-2018, process model); [11•], - 3.7 Tg/a (2001-2007 vs 2008-2014, process model and remote sensing). Ruminants [9], 8.2 Tg/a (2000-2010 vs 2010-2015, inventory); [8], $11.7 \mathrm{Tg} / \mathrm{a}$ (2003 vs 2010, inventory). Oil and natural gas: [5], $5 \mathrm{Tg} / \mathrm{a}$ (1999-2006 vs 2007-2011, inventory); [71], $13 \mathrm{Tg} / \mathrm{a}$ (2008 vs 2014, $\mathrm{C}_{2} \mathrm{H}_{6}$ proxy, USA only); [7], > $20 \mathrm{Tg} / \mathrm{a}$ (2009 vs $2014, \mathrm{C}_{2} \mathrm{H}_{6}$ proxy);

assumed $\mathrm{CH}_{4}$ loss rate relative to production, which varies between production systems and countries with large differences between local estimates of $<1$ and $17 \%$ (e.g. [80, 81]). A best TD estimate derived from global $\left[\mathrm{CH}_{4}\right]$ values is $2-4 \%$ [5]. Regional $\mathrm{CH}_{4}$ emissions derived from leakage rates have been shown to be underestimated [78] and may miss emissions not tied to economic data, e.g. from abandoned wells [82]. Unconventional O-NG production has increased mostly in the USA, but detected emission increases in this region are controversial. While satellite-derived emission increases post2007 are equivalent to $10 \%$ [83], reconstructions from surface $\left[\mathrm{CH}_{4}\right]$ find no increase in US emissions [79•].

In addition to $\mathrm{O}-\mathrm{NG}$ production, $\mathrm{BU}$ coal gas $\mathrm{CH}_{4}$ emissions have increased $>6.5 \mathrm{Tg} / \mathrm{a}$ between 2002 and 2011 [5] (Figs. 1d, 2b). Inversions of satellite data [40] and flask measurements [72] show $5.5 \mathrm{Tg} / \mathrm{a}$ higher emissions between 2005 and 2010 and $10 \mathrm{Tg} / \mathrm{a}$ between 2006 and 2011, respectively, for China alone. The latter study shows a steepening of the emission increase in 2005. These TD estimates agree well with BU increases of $\sim 12 \mathrm{Tg}$ /a between 2000 and 2010 with a steepening in 2002 [73].

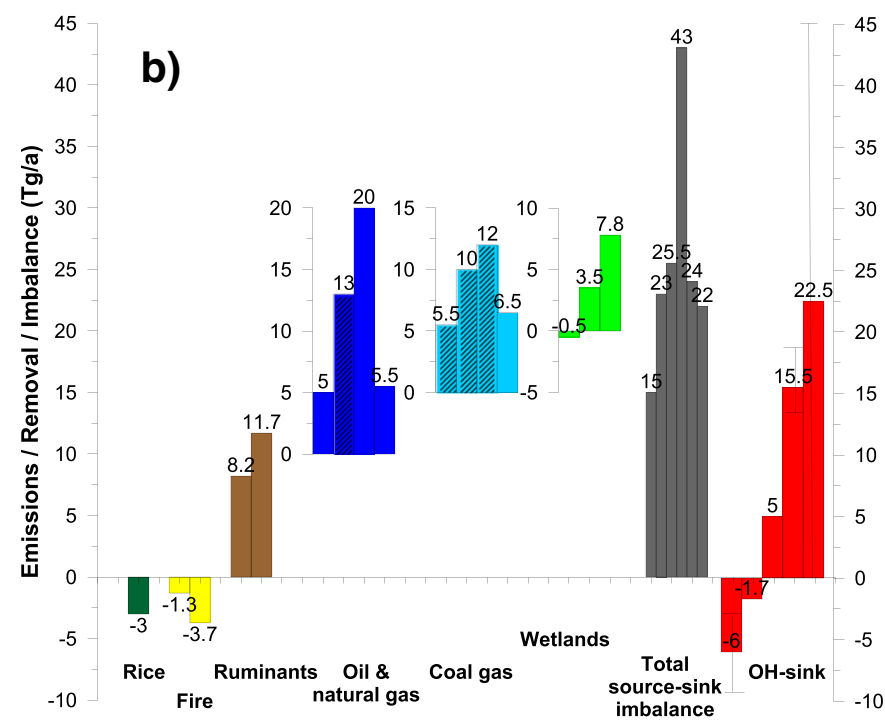

[6], 5.5 Tg/a (1999-2006 vs 2007-2012, inventory). Coal gas: [40], $5.5 \mathrm{Tg} / \mathrm{a}$ (2010 vs 2015, inversion of satellite $\left[\mathrm{CH}_{4}\right]$, China only); [72], $10 \mathrm{Tg} / \mathrm{a}$ (2006 vs 2011, inversion of surface $\left[\mathrm{CH}_{4}\right]$, China incl. industry); [73], $12 \mathrm{Tg} / \mathrm{a}$ (2000 vs 2010, inventory, China only); [5], $6.5 \mathrm{Tg} / \mathrm{a}(2002$ vs 2011, inventory). Wetlands: [13•], $-0.5 \mathrm{Tg} / \mathrm{a}(1999-2006$ vs $2007-$ 2012, process model ensemble constrained by $\left.\left[\mathrm{CH}_{4}\right]\right) ;[74], 3.5 \mathrm{Tg} / \mathrm{a}$ (1999-2006 vs 2007-2014, process model constrained by $\left[\mathrm{CH}_{4}\right]$ ); [14•], $7.8 \mathrm{Tg} / \mathrm{a}$ (1999-2007 vs 2007-2016, process model). Total increase in source-sink imbalance during the renewed rise from whole-budget models (see Table 1 for details): [66], $15 \mathrm{Tg} / \mathrm{a}$; [69], $23 \mathrm{Tg} / \mathrm{a}$; [68], $25.5 \mathrm{Tg} / \mathrm{a}$; [65], $43 \mathrm{Tg} / \mathrm{a}$; [64]: combined BU inventories, $24 \mathrm{Tg} / \mathrm{a}$, [64], inversion ensemble, $22 \mathrm{Tg} / \mathrm{a}$. OH sink: [75], $6 \mathrm{Tg} / \mathrm{a}$ (2000 vs 2010, ACTM ensemble); [18], 1.7 Tg/a (1999-2006 vs 2007-2014, mechanistic model); [15•], - $5 \mathrm{Tg} / \mathrm{a}$ (1999-2006 vs 2007-2014, box model constrained by MCF); [17], $-15.5 \mathrm{Tg} / \mathrm{a}$ (2002-2006 vs 2007-2011, box model constrained by MCF); [16], $22.5 \mathrm{Tg} / \mathrm{a}$ (2003 vs 2016, box model constrained by MCF)

\section{Wetlands}

Process-based wetland emission models simulate $\mathrm{CH}_{4}$ release in response to climate, $\left[\mathrm{CO}_{2}\right]$ and biogeochemical forcing. The parameterisation of the emission response to temperature is a large source of model uncertainty, with temperature as the dominant driver in some models [84]. However, in most models, precipitation and wetland area are the main control of emissions. ENSO switched from drier El Niño predominance to wetter La Niñas around the start of the renewed rise but plays a minor role in global $\left[\mathrm{CH}_{4}\right]$ and $\delta^{13} \mathrm{CH}_{4}$ trends [4]. The correlation between tropical precipitation and TD wetland emissions is strong until 2005, but weak thereafter [65], negating a clear link between the main control and reconstructed fluxes of at least that wetland model. Over the past 30 years, there have been gradual trends for a widening of the tropical belt due to an expansion of the Hadley cell [85] but a narrowing of the ITCZ [86] with unclear consequences for tropical wetland emissions due to changing precipitation patterns. Global wetland area decreased slightly during the renewed rise $(-3.4 \%$ tropical but $+1.8 \%$ boreal) with no 


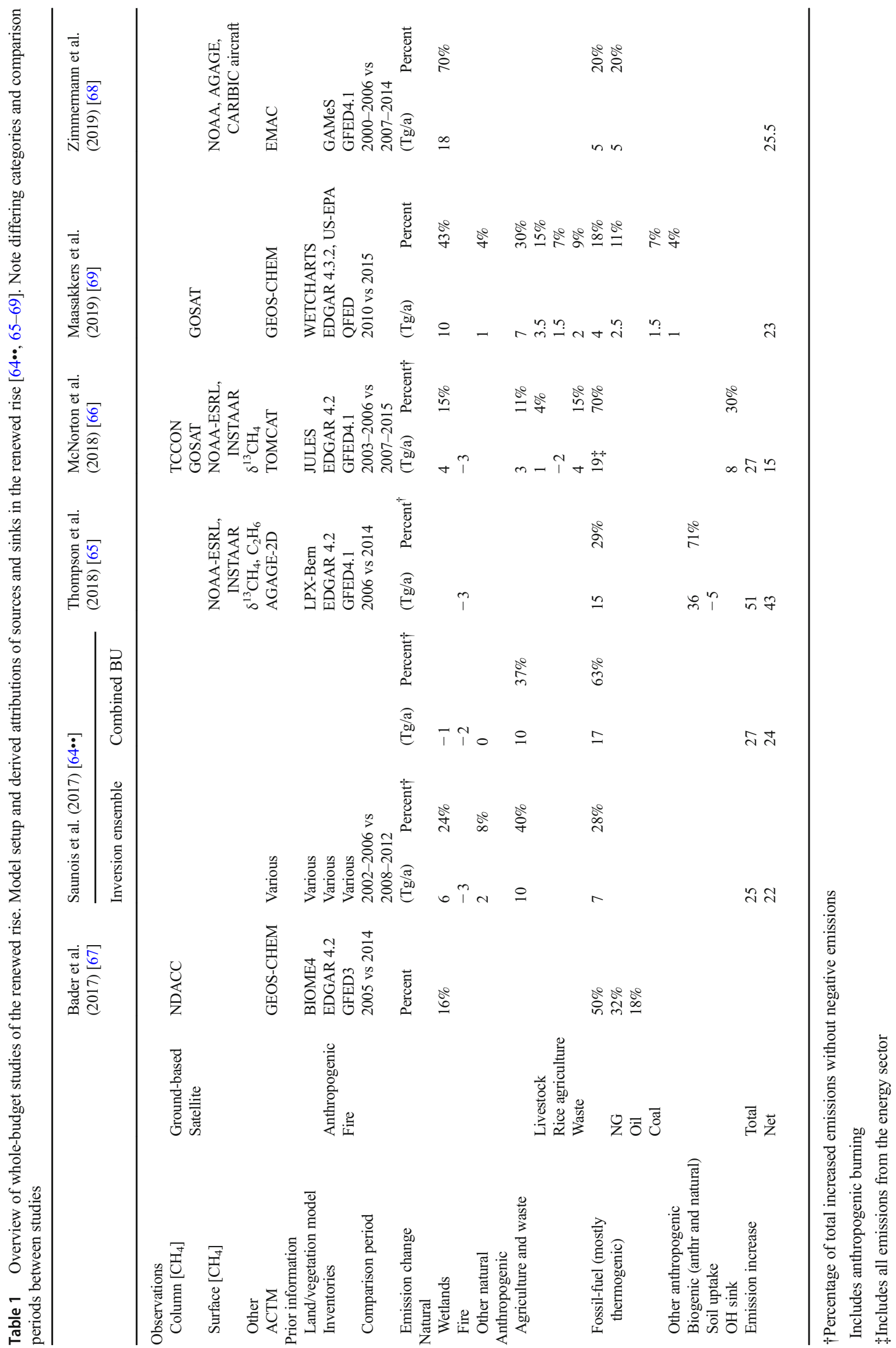


notable temperature change in wetland regions [13•]. However, record temperatures since 2014 may have caused another step increase in $\mathrm{CH}_{4}$ emissions [2••]. In a wetland model coupled with an atmospheric chemistry transport model (ACTM) and calibrated against observed $\left[\mathrm{CH}_{4}\right]$, emissions did not decline at the onset, but possibly later during the plateau. Modelled emissions were $\sim 3.5 \mathrm{Tg} / \mathrm{a}$ higher in 20072014 versus 1993-2006 [74] (Fig. 2b). Another model forced with various climate records gives a $7.8 \mathrm{Tg} / \mathrm{a}$ difference (2000-2006 vs 2007-2014) [14•] (Fig. 1i), but only for reanalysis data that better represent tropical variability than applied elsewhere $[13,74 \cdot]$. However, the divergent estimates $(-5.4$ to $+4.5 \mathrm{Tg} / \mathrm{a} ; 2000-2006$ vs. $2007-2012)$ within a model ensemble for identical forcing [13•] illustrate the caveats of single-model estimates (Fig. 1h).

\section{Biomass Burning}

Biomass burning includes natural and anthropogenic fires and is strongly climate dependent. A reconstruction of fire emissions based on satellite estimates of burned area shows a $2 \mathrm{Tg} / \mathrm{a}$ drop right at the onset of the renewed rise (Global Fire Emissions Database version 4, incl. small fires, (GFED4s) [10]) (Figs. 1g, 2b). Calibration with satellite data of [CO] (a fire proxy) brings the difference to $3.7 \mathrm{Tg} / \mathrm{a}[11 \bullet]$, explaining the post-2007 $\delta^{13} \mathrm{CH}_{4}$ decrease with the decline of the most ${ }^{13} \mathrm{C}$ enriched [25 $]$ source. Including the low- and high-fire years of 1999-2001 and 2015, respectively, lowers the GFED4s difference between plateau and renewed rise by $40 \%$, suggesting a smaller influence on the $\delta^{13} \mathrm{CH}_{4}$ evolution. It is not clear if the step change is a shift between different regimes or an expression of high IAV in biomass burning. The FAO and FINN fire reconstructions do not show a similar break [64••]. A longer term decline in global burned area shows a pronounced low of burning after 2007 but strong fire activity in 2011 and 2012 [87]. The drop could be caused by a shift from pre-dominant El Niños, which enhance global biomass burning [88], to predominant La Niñas. However, an influence of ENSO throughout the atmospheric $\delta^{13} \mathrm{CH}_{4}$ record is not evident [4], suggesting that it is unlikely that the ENSO shift can explain the trends in both $\left[\mathrm{CH}_{4}\right]$ and $\delta^{13} \mathrm{CH}_{4}$ as hypothesised [63].

\section{Waste Management}

Methane emissions from waste management are expected to scale with population [64*0] and therefore contribute to the emissions increase during the renewed rise but probably not to its sudden onset.

\section{Role of Sink(s)}

Methane is removed from the atmosphere via reaction with $\mathrm{OH}\left(\sim 84 \%\right.$ of all $\mathrm{CH}_{4}$ removal [20••]), soil uptake $(\sim 28 \pm$
$19 \mathrm{Tg} / \mathrm{a} ; \sim 5 \%$ [20••]; with an unquantified contribution from caves [89]), Cl oxidation in the marine boundary layer (MBL) $(\leq 13 \mathrm{Tg} / \mathrm{a} ;<2.5 \%[90-92])$ or loss to the stratosphere $(51 \mathrm{Tg} /$ a; $8 \%[20 \bullet \cdot)$.

Reconstructions of soil uptake over the last $\sim 30$ years range from $\sim 5 \mathrm{Tg} / \mathrm{a}$ decline in forest soils [93] to total increases of similar magnitude [94]. In the longer term, soil uptake is expected to increase due to rising $\left[\mathrm{CH}_{4}\right]$ and soil temperatures, with countereffects from higher soil moisture and nitrogen deposition [93].

The MBL chlorine sink is small with poorly constrained variability [90-92]. There is no clear evidence that its strong isotopic fractionation influenced $\delta^{13} \mathrm{CH}_{4}$ trends [66]. A strong role of stratospheric-tropospheric exchange and stratospheric $\mathrm{CH}_{4}$ removal is not evident in total atmospheric column measurements of $\left[\mathrm{CH}_{4}\right]$ [67]. Back mixing of $\mathrm{CH}_{4}$-depleted stratospheric air changes tropospheric $\delta^{13} \mathrm{CH}_{4}$ by $\leq 0.5 \%$ o [95], so the impact on recent trends is likely small.

The hydroxyl sink has the largest potential to alter global $\left[\mathrm{CH}_{4}\right]$ trends. $\mathrm{As} \mathrm{CH}_{4}$ in turn is a major $\mathrm{OH}$ sink, rising $\left[\mathrm{CH}_{4}\right]$ is expected to depress $\mathrm{OH}$ levels. Hydroxyl has a lifetime of $1.5 \mathrm{~s}$ and cannot be measured directly at large scale. Hydroxyl estimates are based on compounds it destroys (e.g. ${ }^{14} \mathrm{CO}$; or methyl chloroform, MCF). The quantifications are hampered by uncertainties in source terms and the multitude of factors influencing $\mathrm{OH}[15 \bullet, 31]$. Such studies show no declining $\mathrm{OH}[15 \bullet, 96]$. Process-based $\mathrm{OH}$ reconstructions using ACTMs also show steady $\mathrm{OH}[18,31,97]$ or a long-term $\mathrm{OH}$ increase [98]. Environmental changes affecting $\mathrm{OH}$ production (humidity, $\mathrm{NO}_{x}$ fluxes, ozone levels and tropospheric temperature) buffer $\mathrm{OH}$ against changes of its sinks like $\mathrm{CH}_{4}$ and $\mathrm{CO}$. [99] IAV of $\mathrm{OH}$ is small at $\sim 2 \%\left[15^{\bullet}, 18\right]$ but can explain the onset of the $\left[\mathrm{CH}_{4}\right]$ and $\delta^{13} \mathrm{CH}_{4}$ plateau $[16,62 \cdot, 100]$ (Fig. 2a). Decreasing $\mathrm{OH}$ after 2006, as indicated by MCF, has been proposed to contribute to [17], or account for [16], the renewed rise. One ACTM supports OH growth until 2009 and subsequent flattening of that trend, initially dampening and then steepening the renewed rise [98]. This would soften the step increase in emissions between 2006 and 2008 derived for steady $\mathrm{OH}$ [64••], which cannot be matched in source reconstructions (Fig. 1). Accounting for model biases in previous studies $[16,17]$ lowers the IAV of $\mathrm{OH}$ and weakens the evidence for decreased $\mathrm{OH}$ during the renewed rise [15•]. A process-based $\mathrm{OH}$ reconstruction backed by ACTM results does not support a substantive role of hydroxyl in the plateau [18] (Fig. 1k). Observed $\left[\mathrm{CH}_{4}\right]$ and $\delta^{13} \mathrm{CH}_{4}$ changes can be matched in a box model for stable emissions, but only assuming extreme, coincident changes in all major sinks $[2 \cdot \bullet]$. IAV of $\mathrm{OH}$ in this scenario exceeds process-based estimates twofold [18]. Even then, the fit to observed $\delta^{13} \mathrm{CH}_{4}$ is poor because $\delta^{13} \mathrm{CH}_{4}$ responds more slowly to sink than to emission changes [2••].

An ACTM experiment suggests that $\mathrm{OH}$ changes neither caused the strong variability in source-sink imbalance until 
2007 nor contributed to the plateau onset and the renewed rise. To the contrary, a postulated $\leq 2 \% \mathrm{OH}$ increase between 2000 and 2010 would require 3-9 $\mathrm{Tg} / \mathrm{a}$ of additional emissions for the observed $\left[\mathrm{CH}_{4}\right]$ trend [75].

$\mathrm{OH}$ reconstructions allow for a range of emission scenarios but do not provide robust evidence for $\mathrm{OH}$-driven $\left[\mathrm{CH}_{4}\right]$ trends. Hypothetically, $\mathrm{OH}$ changes could explain the abruptness of the $\left[\mathrm{CH}_{4}\right]$ change through a step change or the crossing of a threshold in atmospheric circulation or chemistry.

\section{Geographic Attribution}

Quantifying where emissions originate and how they change in specific regions allows attribution to known local sources. In turn, the location of sources influences their impact on local and global $\left[\mathrm{CH}_{4}\right]$. Boreal sources are further from the tropical $\mathrm{OH}$ maximum, so that the lifetime of their emitted $\mathrm{CH}_{4}$ exceeds the lifetime of tropical emissions by 7\% [68]. Transport of boreal $\mathrm{CH}_{4}$ is also shallower, increasing surface observations more than rapidly convected tropical sources $[2 \bullet \bullet]$. Stratospheric $\mathrm{CH}_{4}$ does not increase significantly during the renewed rise [67] and the rate of increase in the mid-upper troposphere is lower than at the surface [101], pointing to surface emissions as the cause of the renewed rise.

Several sources have distinctive latitudinal distribution [70, 102]. According to [102], the following main peaks are observed: biomass burning $20^{\circ} \mathrm{S}$ to $0^{\circ}$ and around $60^{\circ} \mathrm{N}$; tropical wetlands $20^{\circ} \mathrm{S}$ to $10^{\circ} \mathrm{N}$; boreal wetlands around $60^{\circ} \mathrm{N}$; rice $10^{\circ} \mathrm{S}$ to $40^{\circ} \mathrm{N}$. The remaining anthropogenic emissions show a broad distribution $40^{\circ} \mathrm{S}$ to $60^{\circ} \mathrm{N}$, peaking around $40^{\circ}$ $\mathrm{N}$. Regional detection of $\left[\mathrm{CH}_{4}\right]$ anomalies has inherent uncertainties from limitations in geographic coverage and/or precision of observations [103], but several studies have attempted regional attributions. Emissions as estimated in one remote sensing study are highest in temperate Eurasia, followed, in order, by tropical Africa, Asia and South America, and equal contributions from various temperate regions [102]. Emission hotspots include eastern China (particularly the north-east, where coal mining is a known source), India (livestock, coal and rice) and South Asia (wetlands, rice and livestock), as well as central Africa and northern South America (wetlands and livestock). O-NG production areas and industrial regions such as South Central US, central Russia and Europe also stand out in satellite observations and inversion studies [102-104]. Source regions north of $60^{\circ}$, not covered by satellites, may be underestimated.

Spatial variability of $\left[\mathrm{CH}_{4}\right]$ like the interhemispheric difference (IHD) identifies regions of strong growth, but correct interpretation must account for atmospheric transport [105]. The IHD indicates the ratio between northern and southern hemisphere sources. In 1991, the IHD suddenly decreased, possibly due to the breakdown of the Soviet Union and its fossil fuel production. A step increase in 2005 indicates stronger growth of northern hemispheric sources $[105,106]$. A zonal attribution reveals growth anomalies at specific latitudes for certain years, e.g. in boreal regions in 2007 [2••], the northern tropics in 2011 and the southern tropics in 2014 [105]. Generally, growth is concentrated in the northern tropics until 2014 and all tropical zones afterwards [2••]. This would be consistent with growth due to decreased $\mathrm{OH}$, which is most abundant in the tropics. However, the observed lack of

${ }^{13} \mathrm{C}$ depletion in tropical air rather fits enhanced emissions from existing, low- $\delta{ }^{13} \mathrm{CH}_{4}$ tropical sources like wetlands or agriculture $[2 \bullet \bullet$. No latitudinal zone experienced sustained emission increases during all years $[2 \bullet \bullet, 105]$. This IAV in geographic $\left[\mathrm{CH}_{4}\right]$ growth is more consistent with meteorologically controlled natural sources than anthropogenic emissions [2••]. In contrast, the dominant northern hemispheric source latitudes for the renewed growth host mostly industrial (incl. fossil fuel) and agricultural sources. Three-dimensional attributions based on inversions of surface or satellite $\left[\mathrm{CH}_{4}\right]$ records largely agree with tropical and northern temperate source regions for the increase, although the weighting differs. Some studies report higher emission increases in northern temperate zones [107]; others show a $\sim 8 \mathrm{Tg} / \mathrm{a}$ step change in the southern extra-tropics in 2007 and the main increase in the tropics $[65,108,109]$. An inversion ensemble from 8 different ACTMs finds $80 \%$ of the growth from $90^{\circ} \mathrm{S}$ to $30^{\circ} \mathrm{N}$ (but no significant emission increase from $>60^{\circ} \mathrm{N}$ ) [64••]. In contrast, BU estimates in the same study place $80 \%$ of the growth in $30^{\circ} \mathrm{N}-60^{\circ} \mathrm{N}$. Inversions may wrongly allocate emissions to the tropics because they are poorly constrained by measurements. However, inversions using BU emissions as prior show that they are overestimated, particularly in East Asia $[64 \bullet \cdot, 65,66]$. Recent inversion studies agree on the highest growth from eastern and southern Asia (including China and India) and contributions from tropical northern Africa and the Middle East [64••, 66, 69, 108]. More controversial are increases from S. America (not supported by [66]). The trends for N. America range from $\sim 25 \%$ of the global increase [66] to a slight decrease [108]. Overall, the estimates agree qualitatively with $\mathrm{BU}$ emissions increases in China, Africa and India, to a lesser degree with minor contributions from the USA but not with overestimated BU increases from temperate Eurasia/Japan [64••].

\section{Clues from Timing of Changes}

The drop in the source-sink imbalance at plateau onset occurred directly after the Mt. Pinatubo volcanic eruption. This caused perturbances to the wetland source and atmospheric chemistry but only for a few years [110].

The renewed rise started with a step change in the sourcesink imbalance of $\sim 24 \mathrm{Tg}$ /a between 2000-2006 and 20082012 , with no trends before and after [64••]. The acceleration from 2014 onwards is caused by another step change to 
$43 \mathrm{Tg} / \mathrm{a}$ imbalance $[2 \bullet \bullet]$. Trend changes in specific sources or sinks coinciding with the onset of the renewed rise may identify an underlying process. BU inventories have been investigated by the GCP [64••] (see also Fig. 1). Biomass burning shows a significant drop in some, but not all, fire reconstructions $[11 \bullet, 64 \bullet \cdot]$. Northern hemisphere ethane started to increase exactly with the renewed rise [7] but the implied increase in $\mathrm{O}-\mathrm{NG} \mathrm{CH}_{4}$ emissions is controversial [79•, 83]. Longer term increases in coal and total fossil fuel emissions steepen around 2002 [5], preceding the renewed rise, as do livestock emissions [8]. A proposed $\mathrm{OH}$ decrease around the start of the renewed rise $[16,17]$ has been called into question $[15 \cdot, 18]$. Wetlands show high IAV and no clear change around the renewed rise $[13 \bullet, 64 \bullet \cdot]$.

\section{Clues from the Isotope Budget}

Different isotope systems constrain the methane budget, e.g. radiocarbon or deuterium/hydrogen ratio, but $\delta^{13} \mathrm{CH}_{4}$ is the most commonly used and powerful. Atmospheric $\delta^{13} \mathrm{CH}_{4}$ paralleled $\left[\mathrm{CH}_{4}\right]$ trends until the end of the plateau. With the renewed rise, $\delta^{13} \mathrm{CH}_{4}$ decreased $[2 \bullet \bullet, 62 \bullet$ (Fig. 1c). The isotopic signature of a methane source $\left(\delta^{13} \mathrm{C}_{\mathrm{S}}\right)$ varies with environmental conditions and there can be large $\delta^{13} \mathrm{C}_{\mathrm{S}}$ ranges between individual measurements for a given source. However, recent studies have improved $\delta^{13} \mathrm{C}_{\mathrm{S}}$ estimates for various emission types $[28,111,112 \cdot 113 \bullet, 114]$. Globally averaged values of characteristic $\delta^{13} \mathrm{C}_{\mathrm{S}}$ can be defined for three source categories, dependent on the pathway of methane formation: biogenic methane (e.g. wetland and agricultural emissions) with $\delta^{13} \mathrm{C}_{\mathrm{S}}$ of $\sim-62 \%$, fossil fuel emissions (predominantly thermogenic) $\sim-44 \%$ and biomass burning $22 \% 0$ [25•]. Changes in the relative source contributions from each category alter atmospheric $\delta^{13} \mathrm{CH}_{4}$. Similarly, sinks produce characteristic isotope effects as ${ }^{12} \mathrm{CH}_{4}$ is removed preferentially. Derived from these principles and atmospheric $\delta^{13} \mathrm{CH}_{4}$ trends, the isotopic signatures of the cumulative "lost" and "additional" emissions of the plateau onset and renewed rise closely match thermogenic and biogenic emissions, respectively, when assuming changes in a single source type [62•]. Combinations of source (and sink) changes can be tested against the same observed isotope signal. Alternative solutions include (i) $\mathrm{OH}$ changes as sole cause of the plateau onset $[62 \cdot, 100]$ (Fig. 2a); (ii) rising fossil fuel and biomass burning emissions during plateau onset, balanced by decreasing wetland emissions (a more consistent scenario with observed latitudinal changes) [115]; (iii) increases in biogenic as well as fossil fuel emissions causing the renewed rise while biomass burning drops $[11 \bullet, 64 \bullet \cdot]$.

Possibly, temporal changes in $\delta^{13} \mathrm{C}_{\mathrm{S}}$ of a given source category cause, or contribute to, the post-2007 $\delta^{13} \mathrm{CH}_{4}$ trend. Wetland and rice paddy $\delta^{13} \mathrm{C}_{\mathrm{S}}$ can change over time due to changes in the biochemical pathway of methanogenesis, methane production versus oxidation balance (regulated by water table), plant precursor material and other factors [116]. However, these changes can be expected to average out over time and space as demonstrated for boreal wetlands, where highly spatially and temporally variable $\delta^{13} \mathrm{C}_{\mathrm{S}}$ in surface measurements produce a narrowly defined source signature when integrated in aircraft trajectories [113•]. Further, a strong global correlation between flux rates and $\delta^{13} \mathrm{C}_{\mathrm{S}}$ of wetland ecosystems (as expected for changing production/oxidation ratios) is absent in the ice core records [117]. $\delta^{13} \mathrm{C}_{\mathrm{S}}$ changes with shifting nutrient cycling and vegetation occur on timescales of ecosystem reorganisation [118]. Over the past 30 years, it is unlikely that environmental factors substantially changed $\delta^{13} \mathrm{C}_{\mathrm{S}}$ of a given point source.

Instead, $\delta^{13} \mathrm{C}_{\mathrm{S}}$ of a source type could have changed through geographic or economic shifts [119•]. Emission inventories for 1990-2010 indicate shifts to ${ }^{13} \mathrm{C}$-rich coal in China and more livestock emissions from the tropics (where more ${ }^{13} \mathrm{C}$ enriched feed from $\mathrm{C}_{4}$ plants leads to lower $\delta^{13} \mathrm{C}_{\mathrm{S}}$ ). For other source types, $\delta^{13} \mathrm{C}_{\mathrm{S}}$ remains unchanged. The suggested shift to higher coal $\delta^{13} \mathrm{C}_{\mathrm{S}}$ requires compensating shifts in other sources or sinks to match the observed atmospheric $\delta^{13} \mathrm{CH}_{4}$ trend. As livestock emissions are more ${ }^{13} \mathrm{C}$-depleted than cumulative emissions, their shift towards higher $\delta^{13} \mathrm{C}_{\mathrm{S}}$ requires larger livestock emissions for the same $\delta^{13} \mathrm{CH}_{4}$ trend. The fracking boom shifted production from conventional gas to more ${ }^{13} \mathrm{C}$-depleted shale gas, lowering the $\delta^{13} \mathrm{C}_{\mathrm{S}}$ of fossil fuel emissions [120]. This scenario accommodates an increase in fossil fuel emissions equivalent to $70 \%$ of the total rise (if balanced by observed biomass burning reductions [11 ${ }^{\bullet}$ within the $\delta^{13} \mathrm{CH}_{4}$ constraints [62•]). However, such an emission footprint of unconventional gas production, mostly in the USA, is not evident [79•]. Shifts in $\delta^{13} \mathrm{C}_{\mathrm{S}}$ should be considered for best estimates of the methane budget but are unlikely to play a large role in the $\delta^{13} \mathrm{CH}_{4}$ decrease that coincides with the renewed rise.

\section{Budget Analyses}

Optimised budget reconstructions minimise the mismatch between the expected atmospheric signal from prior emission estimates and atmospheric observations. Such studies are influenced by the choice of prior information and they cannot identify source types. However, the derived geographic information combined with prior source distribution, isotope information and other proxies may allow for constraints on colocated emissions for improved budget estimates.

Major budget shifts between 1910 and 2010, as reconstructed by ACTM with optimised emissions based on inventories, include a reduction in $\mathrm{CH}_{4}$ lifetime that was mainly driven by increased $\mathrm{Cl}$ removal (due to anthropogenic $\mathrm{Cl}$ and faster reactions in a warming atmosphere) and occurred mainly between 1965 and 1990 [106]. The IHD increased ever 
more steeply until 1990, indicating increasing importance of northern over southern hemispheric emissions. The doubling of emissions needed to increase $\left[\mathrm{CH}_{4}\right]$ by $\sim 900 \mathrm{ppb}$ between 1900 and 2010 is attributed to agriculture, fossil fuels, wetlands and biomass burning, with dominant increases from livestock emissions 1950-1980 and the O-NG sector 19701990 [106].

The onset of the plateau is marked by a $\sim 9 \mathrm{Tg} / \mathrm{a}$ reduction of emissions relative to $\mathrm{CH}_{4}$ removal in the early 1990 s [62•]. TD reconstructions attribute the plateau onset to declining fossil fuel emissions during the breakdown of Soviet industries $[62 \cdot, 65,105,106]$ (Fig. 2a). The timing and magnitude of a BU 30\% drop in Soviet emissions match the emission reduction without need for a sink increase [6]. A sudden drop in fossil fuels in the 1990s is not evident in ethane [121]. In a $3 \mathrm{D}$ inversion, the plateau onset is explained with stable total emissions, while $\delta^{13} \mathrm{CH}_{4}$ suggests a balance of increasing fossil fuel, livestock and waste emissions, with decreasing biomass burning, wetland and rice emissions. This study considers a fossil fuel decrease unlikely because it would require an unrealistic increase of waste emissions to balance the latitudinal $\left[\mathrm{CH}_{4}\right]$ budget [115]. A rise in fossil fuel emissions, and other anthropogenic sources, compensated by lowered wetland emissions particularly in the latter part of the plateau, is also inferred by other studies [64••]. In a forward ACTM simulation, continuous $\mathrm{OH}$ growth contributes to $\left[\mathrm{CH}_{4}\right]$ stabilisation despite increasing emissions [98]. MCF records allow for a scenario where the plateau is caused by higher $\mathrm{OH}$ removal while emissions remained stable $[62 \bullet, 100]$ or increased [16], which contrasts with other $\mathrm{OH}$ reconstructions [18].

For the renewed rise, most whole-budget reconstructions find wetlands as the major source of IAV in $\left[\mathrm{CH}_{4}\right]$ (together with biomass burning) but not significant contributors to a sustained trend $[64 \bullet \bullet, 108,115]$ (Table 1). This is consistent with, and possibly due to, prior information from wetland process models. Other studies find wetland contributions to the renewed rise that range from minor $[66,67]$ to dominant, i.e. $40 \%$ or $70 \%$ of the increase $[68,69]$. Fossil fuel emissions are consistently seen as a contributor to the renewed rise with estimates from 20 to $70 \%$ of the total emission increase [64••, 65-69] (Table 1). Emissions from rice cultivation are generally estimated as steady or declining (e.g. [66]). Higher livestock emissions, together with emissions from waste management, are estimated to be dominant at $55 \%$ [64・•] or important $[65,69$, $108]$ contributions to the renewed rise while other studies see a minor role $[66,68]$. Biomass burning emissions are generally estimated to have declined, which is consistent with prior information [10] and necessary to balance the $\delta^{13} \mathrm{CH}_{4}$ impact of increasing fossil fuels. Whole-budget studies that independently assess sink changes vary from $\mathrm{OH}$ changes that account for $30 \%$ of the renewed rise [66] to a small or non-significant role [65, 69]. Other individual sources and sinks are not reported to affect the renewed rise.

The above studies differ in model design, prior information, constraining observations, grouping of source types, treatment of sinks, model regions and periods of comparison (Table 1). The GCP analysed the output of eight global inverse systems [64.0] (note that the above-mentioned results from [64.•] refer to the ensemble mean). All inversions agree on increasing agriculture and waste emissions, while fossil fuel emission trends are rising, stable or decreasing. To satisfy the $\delta^{13} \mathrm{CH}_{4}$ constraints for additional emissions [62•], fossil fuel increases cannot exceed the biogenic increase (wetlands, agriculture and waste) $[64 \cdot 0]$. The ensemble mean attributes the majority of the renewed rise (40\%) to agriculture; similar contributions from fossil fuels and wetlands $(\sim 30 \%$ and $\sim 25 \%$, respectively, with large uncertainties), a minor contribution (< $10 \%$ ) from other natural sources and $3 \mathrm{Tg} / \mathrm{a}$ reduction in biomass burning. GCP also reviewed available BU estimates that, in combination, allocate $>60 \%$ of the total increase to fossil fuels, and the remainder to agriculture and waste with insignificant changes in other sources. The mean TD and BU reconstructions agree well for agriculture, waste and biomass burning. Wetlands and fossil fuels can be reconciled within the considerable uncertainties, although BU fossil fuel estimates exceed TD twofold [64••]. Whole-budget reconstructions converge on a multi-source scenario where fossil fuels together with wetland and/or agriculture emissions cause the renewed rise (Table 1). The relative contributions from these categories and the role of the $\mathrm{OH}$ sink remain controversial [64••, 65-69].

The acceleration of $\left[\mathrm{CH}_{4}\right]$ growth in $2014[2 \bullet \bullet]$ has not been widely investigated yet. An emission shift from the northern tropics to all tropical latitudes and an alleged flattening of the $\delta^{13} \mathrm{CH}_{4}$ decrease after 2014 fit with a scenario in which extremely high global temperatures drove the acceleration through increased wetland emissions [2••]. Tropical wetlands are predominantly in the southern tropics and their $\delta^{13} \mathrm{CH}_{4}(\sim-55 \%$ o [114]) is higher than other biogenic sources and the additional emissions of the renewed rise until 2014 [62•]. The hypothesis that increased temperatures already trigger additional natural methane emissions would have severe consequences for future climate-methane feedbacks. Yet, a flattening of $\delta^{13} \mathrm{CH}_{4}$ is not evident in the latest time series [122]. Also, annual $\left[\mathrm{CH}_{4}\right]$ growth in 2014-2017 does not scale with temperature anomalies and diminishes after the first hot year. This rather suggests that $\mathrm{CH}_{4}$ production is enhanced due to accumulated organic material once warming sets in but is not necessarily sustained. One-to-one control of temperature, dominant over other factors like precipitation-driven wetland area and net primary productivity, counters current understanding of wetland $\mathrm{CH}_{4}$ dynamics [13•] and a complex future wetland response to warming $[56 \bullet, 60]$. 


\section{Conclusions: Possible Methane Histories}

The methane system is underconstrained by observations, yet even analyses of the same parameter and studies with similar modelling design find differing explanations for the renewed rise. The strongest consensus is that eastern and southern parts of Asia are the major region of emission growth during the renewed rise.

One possible scenario sees the breakdown of fossil fuel emissions with the Soviet collapse as cause of the plateau onset. The renewed rise follows from an increase in several source types-most likely coal emissions in East Asia, probably together with livestock and waste emissions while biomass burning declined. Contributions from wetlands are possible and cannot be ruled out for the $\mathrm{OH}$ sink. Such a mix of increasing fossil and biogenic emissions is qualitatively similar to the pre-plateau $\left[\mathrm{CH}_{4}\right]$ growth, yet the $\delta^{13} \mathrm{CH}_{4}$ trends during those periods are fundamentally different. It remains to be seen if biomass burning and wetlands with their inherently high IAV can explain the trends longer term. The timing and trigger of the renewed rise, as well as the pattern of a highly variable source-sink imbalance during the plateau period, also remain unexplained. Evidence from past warming suggests that tropical wetlands are the most probable source to provide a climatemethane feedback, while carbon reservoirs like clathrates and permafrost, as well as the $\mathrm{OH}$ sink, seem to respond weakly to climate forcing. Natural $\mathrm{CH}_{4}$ release of similar size to current anthropogenic sources due to climate change is expected in the future. New metrics for the climate impacts of trace gases highlight that methane is of secondary importance compared to long-lived gases. However, $\left[\mathrm{CH}_{4}\right]$ must be at least stabilised and upwards revision of methane's radiative forcing raises the importance of the necessary emission cuts. Although we cannot identify the currently increasing sources with certainty, emissions must be cut wherever possible.

Acknowledgements This work relies on the work of many groups that measure and model methane in all aspects. Special thanks to researchers that made analytical data and model output available for this study: Julie Nicely, Stijn Naus, Alex Turner, Matt Rigby, John Worden, Ben Poulter, Zhen Zhang, Sylvia Nichol, Julie Wolf, Dan Smale, Joe McNorton and Emmanuel Mahieu. Two anonymous reviewers provided insightful feedback that improved the study.

Funding Information This work was funded by the National Institute of Water and Atmospheric Research through the Greenhouse Gases, Emissions and Carbon Cycle Science Programme.

\section{Compliance with Ethical Standards}

Conflict of Interest The corresponding author states that there is no conflict of interest.
Open Access This article is distributed under the terms of the Creative Commons Attribution 4.0 International License (http:// creativecommons.org/licenses/by/4.0/), which permits unrestricted use, distribution, and reproduction in any medium, provided you give appropriate credit to the original author(s) and the source, provide a link to the Creative Commons license, and indicate if changes were made.

\section{References}

Papers of particular interest, published recently, have been highlighted as:

- Of importance

•• Of major importance

1.• Rubino M, Etheridge DM, Thornton DP, Howden R, Allison CE, Francey RJ, et al. Revised records of atmospheric trace gases $\mathrm{CO} 2, \mathrm{CH} 4, \mathrm{~N} 2 \mathrm{O}$, and delta $\mathrm{C}-13-\mathrm{CO} 2$ over the last 2000 years from Law Dome, Antarctica. Earth Syst Sci Data. 2019;11(2): 473-92. https://doi.org/10.5194/essd-11-473-2019 This paper updates the data sets that tie ice core records into modern atmospheric observations of $\left[\mathrm{CH}_{4}\right]$.

2.• Nisbet E, Manning MR, Dlugockenky EJ, Fisher RE, Lowry D, Michel SE, et al. Very strong atmospheric methane growth in the 4 years 2014-2017: implications for the Paris Agreement. Glob Biogeochem Cycles. 2019;33:318-42. https://doi.org/10.1029/ 2018GB006009 This study documents an acceleration of the renewed rise and joins the discussions of reconstructed methane budget changes and climate policy.

3.• Dlugokencky EJ, Lang PM, Crotwell AM, Mund JW, Crotwell MJ, Thoning KW. Atmospheric methane dry air mole fractions from the NOAA ESRL Carbon Cycle Cooperative Global Air Sampling Network, 1983-2016. In: Division N-EGM, editor. Version: 2017-07-28, . Path: ftp://aftp.cmdl.noaa.gov/data/trace gases/ch4/flask/surface/.2017. This data set forms the foundation for almost all analyses of the methane budget from local to global scale.

4. Schaefer H, Smale D, Nichol SE, Bromley TM, Brailsford GW, Martin RJ, et al. Limited impact of El Nino-Southern Oscillation on variability and growth rate of atmospheric methane. Biogeosciences. 2018;15(21):6371-86. https://doi.org/10.5194/ bg-15-6371-2018.

5. Schwietzke S, Griffin WM, Matthews HS, Bruhwiler LMP. Global bottom-up fossil fuel fugitive methane and ethane emissions inventory for atmospheric modeling. ACS Sustain Chem Eng. 2014;2(8):1992-2001. https://doi.org/10.1021/sc500163h.

6. Höglund-Isaksson L. Bottom-up simulations of methane and ethane emissions from global oil and gas systems 1980 to 2012 . Environ Res Lett. 2017;12(024007). https://doi.org/10.1088/ 1748-9326/aa583e.

7. Helmig D, Rossabi S, Hueber J, Tans P, Montzka SA, Masarie K, et al. Reversal of global atmospheric ethane and propane trends largely due to US oil and natural gas production. Nat Geosci. 2016;9(7):490-5. https://doi.org/10.1038/Ngeo2721.

8. Wolf J, Asrar GR, West TO. Revised methane emissions factors and spatially distributed annual carbon fluxes for global livestock. Carbon Bal Manag. 2017;12. https://doi.org/10.1186/s13021-0170084-y.

9. Dangal SRS, Tian HQ, Zhang BW, Pan SF, Lu CQ, Yang J. Methane emission from global livestock sector during 18902014: magnitude, trends and spatiotemporal patterns. Glob 
Chang Biol. 2017;23(10):4147-61. https://doi.org/10.1111/gcb. 13709.

10. Van der Werf GR, Randerson JT, Giglio L, Van Leeuwen TT, Chen Y, Rogers BM, et al. Global fire emissions estimates during 1997-2016. Earth Syst Sci Data. 2017;9:697-720. https://doi.org/ 10.5194/essd-9-697-2017.

11. Worden JR, Bloom AA, Pandey S, Jiang Z, Worden HM, Walker TW et al. Reduced biomass burning emissions reconcile conflicting estimates of the post-2006 atmospheric methane budget. Nat Commun. 2017;8. https://doi.org/10.1038/s41467-017-02246-0. This paper provides an explanation for the conflicting evidence between $\mathrm{BU}$ fossil fuel emissions and $\delta^{13} \mathrm{CH}_{4}$ trends.

12. Wiedinmyer C, Akagi SK, Yokelson RJ, Emmons LK, Al-Saadi JA, Orlando JJ, et al. The Fire Inventory from NCAR (FINN): a high resolution global model to estimate the emissions from open burning. Geosci Model Dev. 2011;4(3):625-41. https://doi.org/10. 5194/gmd-4-625-2011.

13. Poulter B, Bousquet P, Canadell JG, Ciais P, Peregon A, Saunois M, et al. Global wetland contribution to 2000-2012 atmospheric methane growth rate dynamics. Environ Res Lett. 2017;12(9). https://doi.org/10.1088/1748-9326/aa8391 This multi-model study assesses the role of wetlands in the renewed rise.

14. Zhang Z, Zimmermann NE, Calle L, Hurtt G, Chatterjee A, Poulter B. Enhanced response of global wetland methane emissions to the 2015-2016 El Nino-Southern Oscillation event. Environ Res Lett. 2018;13(7). https://doi.org/10.1088/17489326/aac939 This study demonstrates the relevance of accurate climate forcing for wetland modelling.

15. Naus S, Montzka SA, Pandey S, Basu S, Dlugokencky EJ, Krol M. Constraints and biases in a tropospheric two-box model of OH. Atmos Chem Phys. 2019;19(1):407-24. https://doi.org/10.5194/ acp-19-407-2019 This study reconciles $\mathbf{O H}$ reconstructions from MCF and ACTMs.

16. Turner AJ, Frankenbergb C, Wennberg PO, Jacob DJ. Ambiguity in the causes for decadal trends in atmospheric methane and hydroxyl. Proc Natl Acad Sci U S A. 2017;114(21):5367-72. https:// doi.org/10.1073/pnas.1616020114.

17. Rigby M, Montzka SA, Prinn RG, White JWC, Young D, O'Doherty S, et al. Role of atmospheric oxidation in recent methane growth. Proc Natl Acad Sci U S A. 2017;114(21):5373-7. https://doi.org/10.1073/pnas.1616426114.

18. Nicely JM, Canty TP, Manyin M, Oman LD, Salawitch RJ, Steenrod SD, et al. Changes in global tropospheric $\mathrm{OH}$ expected as a result of climate change over the last several decades. J Geophys Res-Atmos. 2018;123(18):10774-95. https://doi.org/ 10.1029/2018jd028388.

19. Turner AJ, Frankenberg C, Kort EA. Interpreting contemporary trends in atmospheric methane. Proc Natl Acad Sci U S A. 2019;116(8):2805-13. https://doi.org/10.1073/pnas.1814297116 This paper summarises the potential of additional observations to improve reconstructions of the methane budget.

20.• Saunois M, Bousquet P, Poulter B, Peregon A, Ciais P, Canadell JG, et al. The global methane budget 2000-2012. Earth Syst Sci Data. 2016;8(2):697-751. https://doi.org/10.5194/essd-8-697-2016 This study by the GCP provides the most comprehensive assessment of decadal methane budgets.

21. Denman KL, Brasseur GP, Chidthaisong A, Ciais P, Cox PM, Dickinson RE, et al. Couplings between changes in the climate system and biogeochemistry. In: Solomon S, Qin D, Manning MR, Chen ZH, Marquis M, Averyt KB, et al., editors. Climate change 2007: the physical science basis. Contribution of Working Group I to the Fourth Assessment Report of the Intergovernmental Panel on Climate Change. Cambridge and New York: Cambridge University Press; 2007.
22. Lamarche-Gagnon G, Wadham JL, Lollar BS, Arndt S, Fietzek P, Beaton $\mathrm{AD}$, et al. Greenland melt drives continuous export of methane from the ice-sheet bed. Nature. 2019;565(7737):73. https://doi.org/10.1038/s41586-018-0800-0.

23. Yuan JJ, Xiang J, Liu DY, Kang H, He TH, Kim S, et al. Rapid growth in greenhouse gas emissions from the adoption of industrial-scale aquaculture. Nat Clim Chang. 2019;9(4):318. https://doi.org/10.1038/s41558-019-0425-9.

24. Royer S-J, Ferrón S, Wilson ST, Karl DM. Production of methane and ethylene from plastic in the environment. PLoS One. 2018;13(8):e0200574. https://doi.org/10.1371/journal.pone. 0200574.

25. Schwietzke S, Sherwood OA, Ruhwiler LMPB, Miller JB, Etiope G, Dlugokencky EJ, et al. Upward revision of global fossil fuel methane emissions based on isotope database. Nature. 2016;538(7623):88-91. https://doi.org/10.1038/nature19797 This study provides a major reassessment of $\delta^{13} C_{S}$ for various sources.

26. Dalsoren SB, Myhre G, Hodnebrog O, Myhre CL, Stohl A, Pisso I, et al. Discrepancy between simulated and observed ethane and propane levels explained by underestimated fossil emissions. Nat Geosci. 2018;11(3):178. https://doi.org/10.1038/s41561-0180073-0.

27. Petrenko VV, Smith AM, Schaefer H, Riedel K, Brook EJ, Baggenstos D, et al. Minimal geologic methane emissions during Younger Dryas - Preboreal abrupt warming event. Nature. 2017;548:443-6. https://doi.org/10.1038/nature23316.

28. Etiope G, Ciotoli G, Schwietzke S, Schoell M. Gridded maps of geological methane emissions and their isotopic signature. Earth Syst Sci Data. 2019;11(1):1-22. https://doi.org/10.5194/essd-11$1-2019$.

29. Myhre G, Shindell D, Bréon F-M, Collins W, Fuglestvedt JS, Huang J, et al. Anthropogenic and natural radiative forcing. In: Stocker TF, Qin D, Plattner G-K, Tignor M, Allen SK, Boschung J, et al., editors. Climate change 2013: the physical science basis. Contribution of Working Group I to the Fifth Assessment Report of the Intergovernmental Panel on Climate Change. Cambridge and New York: Cambridge University Press; 2013.

30. Shindell DT, Faluvegi G, Koch DM, Schmidt GA, Unger N, Bauer SE. Improved attribution of climate forcing to emissions. Science. 2009;326(5953):716-8. https://doi.org/10.1126/science. 1174760.

31. Holmes CD, Prather MJ, Sovde OA, Myhre G. Future methane, hydroxyl, and their uncertainties: key climate and emission parameters for future predictions. Atmos Chem Phys. 2013;13(1):285302. https://doi.org/10.5194/acp-13-285-2013.

32.• Etminan M, Myhre G, Highwood EJ, Shine KP. Radiative forcing of carbon dioxide, methane, and nitrous oxide: a significant revision of the methane radiative forcing. Geophys Res Lett. 2016;43(24):12614-23. https://doi.org/10.1002/2016g1071930 This study investigates additional impacts on the RF of methane for a substantial upwards revision.

33. Collins WD, Feldman DR, Kuo C, Nguyen NH. Large regional shortwave forcing by anthropogenic methane informed by Jovian observations. Sci Adv. 2018;4(9). https://doi.org/10.1126/sciadv. aas9593.

34. Feldman DR, Collins WD, Biraud SC, Risser MD, Turner DD, Gero PJ, et al. Observationally derived rise in methane surface forcing mediated by water vapour trends. Nat Geosci. 2018;11(4):238. https://doi.org/10.1038/s41561-018-0085-9.

35. Zickfeld K, Solomon S, Gilford DM. Centuries of thermal sealevel rise due to anthropogenic emissions of short-lived greenhouse gases. Proc Natl Acad Sci U S A. 2017;114(4):657-62. https://doi.org/10.1073/pnas.1612066114.

36. Myles RA, Shine KP, Fuglestvedt J, Millar RJ, Cain M, Frame DJ, et al. A solution to the misrepresentations of $\mathrm{CO} 2$-equivalent 
emissions of short-lived climate pollutants under ambitious mitigation. Clim Atmos Sci. 2018;1:16. https://doi.org/10.1038/ s41612-018-0026-8 This work improves the quantification of methane's climate impact relative to other GHGs.

37. van Vuuren DP, Stehfest E, Gernaat DEHJ, Doelman JC, Van den Berg M, Harmsen M, et al. Energy, land-use and greenhouse gas emissions trajectories under a green growth paradigm. Global Environ Chang. 2017;42:237-50. https://doi.org/10.1016/j. gloenvcha.2016.05.008.

38. Fesenfeld LP, Schmidt TS, Schrode A. Climate policy for shortand long-lived pollutants. Nat Clim Chang. 2018;8(11):934-6. https://doi.org/10.1038/s41558-018-0328-1.

39. Masson-Delmotte V, Zhai P, Pörtner H-O, Roberts D, Skea J, Shukla PR, et al., editors. Global warming of $1.5^{\circ} \mathrm{C}$. An IPCC Special Report on the impacts of global warming of $1.5^{\circ} \mathrm{C}$ above pre-industrial levels and related global greenhouse gas emission pathways, in the context of strengthening the global response to the threat of climate change, sustainable development, and efforts to eradicate poverty. Geneva: World Meteorological Organization; 2018.

40. Miller SM, Michalak AM, Detmers RG, Hasekamp OP, Bruhwiler LMP, Schwietzke S. China's coal mine methane regulations have not curbed growing emissions. Nat Commun. 2019;10:303. https://doi.org/10.1038/s41467-018-07891-7.

41. Environmental Protection Agency U. Oil and natural gas sector: emission standards for new, reconstructed, and modified sources. Federal Register. 2016;81(107).

42. Frank S, Havlik P, Stehfest E, van Meijl H, Witzke P, PerezDominguez I, et al. Agricultural non-CO2 emission reduction potential in the context of the 1.5 degrees $\mathrm{C}$ target. Nat Clim Chang. 2019;9(1):66. https://doi.org/10.1038/s41558-018-0358-8.

43. Harmsen JHM, van Vuuren DP, Nayak DR, Hof AF, HoglundIsaksson L, Lucas PL, et al. Long-term marginal abatement cost curves of non-CO2 greenhouse gases. Environ Sci Pol. 2019;99: 136-49. https://doi.org/10.1016/j.envsci.2019.05.013.

44. Comyn-Platt E, Hayman G, Huntingford C, Chadburn SE, Burke EJ, Harper AB, et al. Carbon budgets for 1.5 and 2 degrees $\mathrm{C}$ targets lowered by natural wetland and permafrost feedbacks. Nat Geosci. 2018;11(11):882-6. https://doi.org/10.1038/s41561018-0247-9.

45. Riahi K, van Vuuren DP, Kriegler E, Edmonds J, O'Neill BC, Fujimori $\mathrm{S}$, et al. The shared socioeconomic pathways and their energy, land use, and greenhouse gas emissions implications: an overview. Global Environ Chang. 2017;42:153-68. https://doi. org/10.1016/j.gloenvcha.2016.05.009.

46. Baumgartner M, Kindler P, Eicher O, Floch G, Schilt A, Schwander J, et al. NGRIP CH4 concentration from 120 to 10 kyr before present and its relation to a delta N-15 temperature reconstruction from the same ice core. Clim Past. 2014;10(2): 903-20. https://doi.org/10.5194/cp-10-903-2014.

47. Hopcroft PO, Valdes PJ, O'Connor FM, Kaplan JO, Beerling DJ. Understanding the glacial methane cycle. Nat Commun. 2017;8. https://doi.org/10.1038/ncomms14383.

48. Murray LT, Mickley LJ, Kaplan JO, Sofen ED, Pfeiffer M, Alexander B. Factors controlling variability in the oxidative capacity of the troposphere since the Last Glacial Maximum. Atmos Chem Phys. 2014;14(7):3589-622. https://doi.org/10.5194/acp14-3589-2014.

49. Quiquet A, Archibald AT, Friend AD, Chappellaz J, Levine JG, Stone EJ, et al. The relative importance of methane sources and sinks over the Last Interglacial period and into the Last Glaciation. Quat Sci Rev. 2015;112:1-16. https://doi.org/10.1016/j.quascirev. 2015.01.004.

50. Alexander B, Mickley LJ. Paleo-perspectives on potential future changes in the oxidative capacity of the atmosphere due to climate change and anthropogenic emissions. Curr Pollut Rep. 2015;1(2): 57-69. https://doi.org/10.1007/s40726-015-0006-0.

51. Bock M, Schmitt J, Beck J, Seth B, Chappellaz J, Fischer H. Glacial/interglacial wetland, biomass burning, and geologic methane emissions constrained by dual stable isotopic $\mathrm{CH} 4$ ice core records. Proc Natl Acad Sci U S A. 2017;114(29):E5778-E86. https://doi.org/10.1073/pnas.1613883114.

52. Rhodes RH, Brook EJ, McConnell JR, Blunier T, Sime LC, Fain $\mathrm{X}$, et al. Atmospheric methane variability: centennial-scale signals in the Last Glacial period. Glob Biogeochem Cycles. 2017;31(3): 575-90. https://doi.org/10.1002/2016gb005570.

53. Yang JW, Ahn J, Brook EJ, Ryu Y. Atmospheric methane control mechanisms during the early Holocene. Clim Past. 2017;13(9): 1227-42. https://doi.org/10.5194/cp-13-1227-2017.

54. Rhodes RH, Brook EJ, Chiang JCH, Blunier T, Maselli OJ, McConnell JR, et al. Enhanced tropical methane production in response to iceberg discharge in the North Atlantic. Science. 2015;348(6238):1016-9. https://doi.org/10.1126/science. 1262005.

55. Power MJ, Marlon J, Ortiz N, Bartlein PJ, Harrison SP, Mayle FE, et al. Changes in fire regimes since the Last Glacial Maximum: an assessment based on a global synthesis and analysis of charcoal data. Clim Dyn. 2008;30(7-8):887-907. https://doi.org/10.1007/ s00382-007-0334-x.

56. Dean JF, Middelburg JJ, Rockmann T, Aerts R, Blauw LG, Egger $\mathrm{M}$, et al. Methane feedbacks to the global climate system in a warmer world. Rev Geophys. 2018;56(1):207-50. https://doi. org/10.1002/2017rg000559 This is a comprehensive review of potential climate-methane feedbacks.

57. Mestdagh T, Poort J, De Batist M. The sensitivity of gas hydrate reservoirs to climate change: perspectives from a new combined model for permafrost-related and marine settings. Earth-Sci Rev. 2017;169:104-31. https://doi.org/10.1016/j.earscirev.2017.04. 013.

58. Ruppel CD, Kessler JD. The interaction of climate change and methane hydrates. Rev Geophys. 2017;55(1):126-68. https://doi. org/10.1002/2016rg000534.

59. Anthony KW, von Deimling TS, Nitze I, Frolking S, Emond A, Daanen R, et al. 21st-Century modeled permafrost carbon emissions accelerated by abrupt thaw beneath lakes. Nat Commun. 2018;9. https://doi.org/10.1038/s41467-018-05738-9.

60. Zhang Z, Zimmermann NE, Stenke A, Li X, Hodson EL, Zhu GF, et al. Emerging role of wetland methane emissions in driving 21st century climate change. Proc Natl Acad Sci U S A. 2017;114(36): 9647-52. https://doi.org/10.1073/pnas.1618765114.

61. Voulgarakis A, Naik V, Lamarque JF, Shindell DT, Young PJ, Prather MJ, et al. Analysis of present day and future $\mathrm{OH}$ and methane lifetime in the ACCMIP simulations. Atmos Chem Phys. 2013;13(5):2563-87. https://doi.org/10.5194/acp-13-25632013.

62. Schaefer H, Fletcher SEM, Veidt C, Lassey KR, Brailsford GW, Bromley TM, et al. A 21st-century shift from fossil-fuel to biogenic methane emissions indicated by $13 \mathrm{CH} 4$. Science. 2016;352(6281):80-4. https://doi.org/10.1126/science.aad2705 This study explores the $\delta^{13} \mathrm{CH}_{4}$ trend reversal and provides a stringent constraint for valid reconstructions.

63. Nisbet EG, Dlugokencky EJ, Manning MR, Lowry D, Fisher RE, France JL, et al. Rising atmospheric methane: 2007-2014 growth and isotopic shift. Glob Biogeochem Cycles. 2016;30(9):135670. https://doi.org/10.1002/2016gb005406.

64.• Saunois M, Bousquet P, Poulter B, Peregon A, Ciais P, Canadell JG, et al. Variability and quasi-decadal changes in the methane budget over the period 2000-2012. Atmos Chem Phys. 2017;17(18): 11135-61. https://doi.org/10.5194/acp-17-11135-2017 This study by the GCP provides the most comprehensive assessment of 
contributors to the renewed rise using multi-model analyses and BU evidence.

65. Thompson RL, Nisbet EG, Pisso I, Stohl A, Blake D, Dlugokencky EJ, et al. Variability in atmospheric methane from fossil fuel and microbial sources over the last three decades. Geophys Res Lett. 2018;45(20):11499-508. https://doi.org/10. 1029/2018g1078127.

66. McNorton J, Wilson C, Gloor M, Parker RJ, Boesch H, Feng WH, et al. Attribution of recent increases in atmospheric methane through 3-D inverse modelling. Atmos Chem Phys. 2018;18(24):18149-68. https://doi.org/10.5194/acp-18-181492018.

67. Bader W, Bovy B, Conway S, Strong K, Smale D, Turner AJ, et al. The recent increase of atmospheric methane from 10 years of ground-based NDACC FTIR observations since 2005. Atmos Chem Phys. 2017;17(3):2255-77. https://doi.org/10.5194/acp17-2255-2017.

68. Zimmermann PR, Brenninkmeijer C, Pozzer A, Jöckel P, Zahn A, Houweling $\mathrm{S}$, et al. Model simulations of atmospheric methane and their evaluation using AGAGE/NOAA surface- and IAGOSCARIBIC aircraft observations, 1997-2014. Atmos Chem Phys Discuss. 2018:1-45. https://doi.org/10.5194/acp-2017-1212.

69. Maasakkers JD, Jacob DJ, Sulprizio MP, Scarpelli TR, Nesser H, Sheng JX, et al. Global distribution of methane emissions, emission trends, and $\mathrm{OH}$ concentrations and trends inferred from an inversion of GOSAT satellite data for 2010-2015. Atmos Chem Phys. 2019;19:7859-81. https://doi.org/10.5194/acp-19-78592019.

70. Zhang BW, Tian HQ, Ren W, Tao B, Lu CQ, Yang J, et al. Methane emissions from global rice fields: magnitude, spatiotemporal patterns, and environmental controls. Glob Biogeochem Cycles. 2016;30(9):1246-63. https://doi.org/10.1002/ $2016 \mathrm{gb005381.}$

71. Monks SA, Wilson C, Emmons LK, Hannigan JW, Helmig D, Blake NJ, et al. Using an inverse model to reconcile differences in simulated and observed global ethane concentrations and trends between 2008 and 2014. J Geophys Res-Atmos. 2018;123(19): 11262-82. https://doi.org/10.1029/2017jd028112.

72. Thompson RL, Stohl A, Zhou LX, Dlugokencky E, Fukuyama Y, Tohjima Y, et al. Methane emissions in East Asia for 2000-2011 estimated using an atmospheric Bayesian inversion. J Geophys Res-Atmos. 2015;120(9):4352-69. https://doi.org/10.1002/ 2014jd022394.

73. Zhu T, Bian W, Zhang S, Di P, Nie B. An improved approach to estimate methane emissions from coal mining in China. Environ Sci Technol. 2017;51:12072-80. https://doi.org/10.1021/acs.est. $7 \mathrm{~b} 01857$.

74. McNorton J, Gloor E, Wilson C, Hayman GD, Gedney N, Comyn-Platt E, et al. Role of regional wetland emissions in atmospheric methane variability. Geophys Res Lett. 2016;43(21): 11433-44. https://doi.org/10.1002/2016gl070649.

75. Zhao Y, Saunois M, Bousquet P, Lin X, Hegglin MI, Canadell JG, et al. Inter-model comparison of global hydroxyl radical $(\mathrm{OH})$ distributions and their impact on atmospheric methane over the 2000-2016 period. Atmos Chem Phys Discuss. 2019:1-47. https:// doi.org/10.5194/acp-2019-281.

76. Ganesan AL, Rigby M, Lunt MF, Parker RJ, Boesch H, Goulding $\mathrm{N}$, et al. Atmospheric observations show accurate reporting and little growth in India's methane emissions. Nat Commun. 2017;8: 836. https://doi.org/10.1038/s41467-017-00994-7.

77. Zhang GL, Xiao XM, Biradar CM, Dong JW, Qin YW, Menarguez MA, et al. Spatiotemporal patterns of paddy rice croplands in China and India from 2000 to 2015. Sci Total Environ. 2017;579:82-92. https://doi.org/10.1016/j.scitotenv.2016.10.223.

78. Kort EA, Smith ML, Murray LT, Gvakharia A, Brandt AR, Peischl $\mathrm{J}$, et al. Fugitive emissions from the Bakken shale illustrate role of shale production in global ethane shift. Geophys Res Lett. 2016;43(9):4617-23. https://doi.org/10.1002/2016gl068703.

79. Lan X, Tans P, Sweeney C, Andrews AE, Dlugockenky EJ, Schwietzke $\mathrm{S}$ et al. Long-term measurements show little evidence for large increases in total U.S. methane emissions over the past decade. Geophys Res Lett. 2019; accepted. https://doi.org/10. 1029/2018GL081731. This paper resolves the controversy between rising $\mathrm{CH}_{4}$ and $\mathrm{C}_{2} \mathrm{H}_{6}$ emissions in the USA.

80. Allen DT, Torres VM, Thomas J, Sullivan DW, Harrison M, Hendler A, et al. Measurements of methane emissions at natural gas production sites in the United States. Proc Natl Acad Sci U S A. $2013 ; 110(44): 17768-73$. https://doi.org/10.1073/pnas. 1304880110

81. Brandt AR, Heath GA, Kort EA, O'Sullivan F, Petron G, Jordaan SM, et al. Methane leaks from North American natural gas systems. Science. 2014;343(6172):733-5. https://doi.org/10.1126/ science. 1247045.

82. Kang M, Christian S, Celia MA, Mauzerall DL, Bill M, Miller $\mathrm{AR}$, et al. Identification and characterization of high methaneemitting abandoned oil and gas wells. Proc Natl Acad Sci U S A. 2016;113(48):13636-41. https://doi.org/10.1073/pnas. 1605913113.

83. Sheng JX, Jacob DJ, Turner AJ, Maasakkers JD, Benmergui J, Bloom AA, et al. 2010-2016 methane trends over Canada, the United States, and Mexico observed by the GOSAT satellite: contributions from different source sectors. Atmos Chem Phys. 2018;18(16):12257-67. https://doi.org/10.5194/acp-18-122572018.

84. Zhu Q, Peng C, Ciais P, Jiang H, Liu J, Bousquet $\mathrm{P}$ et al. Interannual variation in methane emissions from tropical wetlands triggered by repeated El Niño Southern Oscillation. Global Change Biology. 2017.

85. Allen RJ, Norris JR, Kovilakam M. Influence of anthropogenic aerosols and the Pacific Decadal Oscillation on tropical belt width. Nat Geosci. 2014;7(4):270-4. https://doi.org/10.1038/ngeo2091.

86. Byrne MP, Pendergrass AG, Rapp AD, Wodzicki KR. Response of the intertropical convergence zone to climate change: location, width, and strength. Current Climate Change Reports. 2018;4(4): 355-70. https://doi.org/10.1007/s40641-018-0110-5.

87. Andela N, Morton DC, Giglio L, Chen Y, van der Werf GR, Kasibhatla PS, et al. A human-driven decline in global burned area. Science. 2017;356(6345):1356-61. https://doi.org/10.1126/ science.aal4108.

88. Chen Y, Morton DC, Andela N, van der Werf GR, Giglio L, Randerson JT. A pan-tropical cascade of fire driven by El Nino/ Southern Oscillation. Nat Clim Chang. 2017;7(12):906. https:// doi.org/10.1038/s41558-017-0014-8.

89. Waring CL, Hankin SI, Griffith DWT, Kertesz MA, Kobylski V, Wilson NL, et al. Seasonal total methane depletion in limestone caves. Sci Rep-Uk. 2017;7. https://doi.org/10.1038/s41598-01707769-6.

90. Hossaini R, Chipperfield MP, Saiz-Lopez A, Fernandez R, Monks $\mathrm{S}$, Feng WH, et al. A global model of tropospheric chlorine chemistry: organic versus inorganic sources and impact on methane oxidation. J Geophys Res-Atmos. 2016;121(23):14271-97. https://doi.org/10.1002/2016jd025756.

91. Gromov S, Brenninkmeijer CAM, Jockel P. A very limited role of tropospheric chlorine as a sink of the greenhouse gas methane. Atmos Chem Phys. 2018;18(13):9831-43. https://doi.org/10. 5194/acp-18-9831-2018.

92. Wang X, Jacob DJ, Eastham SD, Sulprizio MP, Zhu L, Chen QJ, et al. The role of chlorine in global tropospheric chemistry. Atmos Chem Phys. 2019;19(6):3981-4003. https://doi.org/10.5194/acp19-3981-2019. 
93. Ni XY, Groffman PM. Declines in methane uptake in forest soils. Proc Natl Acad Sci U S A. 2018;115(34):8587-90. https://doi.org/ 10.1073/pnas.1807377115.

94. Yu LJ, Huang Y, Zhang W, Li TT, Sun WJ. Methane uptake in global forest and grassland soils from 1981 to 2010. Sci Total Environ. 2017;607:1163-72. https://doi.org/10.1016/j.scitotenv. 2017.07.082

95. Garofalo L, Kanu A, Hoag K, Boering KA. The effects of stratospheric chemistry and transport on the isotopic compositions of longlived gases measured at Earth's surface. Adv Atmos Chem. 2018.

96. Manning MR, Lowe DC, Moss RC, Bodeker GE, Allan W. Shortterm variations in the oxidizing power of the atmosphere. Nature. 2005;436(7053):1001-4. https://doi.org/10.1038/nature03900.

97. Naik V, Voulgarakis A, Fiore AM, Horowitz LW, Lamarque JF, Lin M, et al. Preindustrial to present-day changes in tropospheric hydroxyl radical and methane lifetime from the Atmospheric Chemistry and Climate Model Intercomparison Project (ACCMIP). Atmos Chem Phys. 2013;13(10):5277-98. https:// doi.org/10.5194/acp-13-5277-2013.

98. Dalsoren SB, Myhre CL, Myhre G, Gomez-Pelaez AJ, Sovde OA, Isaksen ISA, et al. Atmospheric methane evolution the last 40 years. Atmos Chem Phys. 2016;16(5):3099-126. https://doi.org/ 10.5194/acp-16-3099-2016.

99. Gaubert B, Worden HM, Arellano AFJ, Emmons LK, Tilmes S, Barre J, et al. Chemical feedback from decreasing carbon monoxide emissions. Geophys Res Lett. 2017;44(19):9985-95. https:// doi.org/10.1002/2017g1074987.

100. McNorton J, Chipperfield MP, Gloor M, Wilson C, Feng WH, Hayman GD, et al. Role of $\mathrm{OH}$ variability in the stalling of the global atmospheric CH4 growth rate from 1999 to 2006. Atmos Chem Phys. 2016;16(12):7943-56. https://doi.org/10.5194/acp16-7943-2016.

101. Zou M, Xiong X, Wu Z, Li SH, Zhang Y, Chen L. Increase of atmospheric methane observed from space-borne and groundbased measurements. Remote Sens-Basel. 2019;11(964). https:// doi.org/10.3390/rs11080964.

102. Alexe M, Bergamaschi P, Segers A, Detmers R, Butz A, Hasekamp O, et al. Inverse modelling of $\mathrm{CH} 4$ emissions for 2010-2011 using different satellite retrieval products from GOSAT and SCIAMACHY. Atmos Chem Phys. 2015;15(1): 113-33. https://doi.org/10.5194/acp-15-113-2015.

103. Cressot C, Pison I, Rayner PJ, Bousquet P, Fortems-Cheiney A, Chevallier F. Can we detect regional methane anomalies? A comparison between three observing systems. Atmos Chem Phys. 2016;16(14):9089-108. https://doi.org/10.5194/acp-16-90892016.

104. Jacob DJ, Turner AJ, Maasakkers JD, Sheng JX, Sun K, Liu X, et al. Satellite observations of atmospheric methane and their value for quantifying methane emissions. Atmos Chem Phys. 2016;16(22):14371-96. https://doi.org/10.5194/acp-16-143712016.

105. Pandey S, Houweling S, Krol M, Aben I, Nechita-Banda N, Thoning K, et al. Influence of atmospheric transport on estimates of variability in the global methane burden. Geophys Res Lett. 2019;46(4):2302-11. https://doi.org/10.1029/2018gl081092.

106. Ghosh A, Patra PK, Ishijima K, Umezawa T, Ito A, Etheridge DM, et al. Variations in global methane sources and sinks during 19102010. Atmos Chem Phys. 2015;15(5):2595-612. https://doi.org/ 10.5194/acp-15-2595-2015.

107. Bruhwiler L, Dlugokencky E, Masarie K, Ishizawa M, Andrews A, Miller J, et al. CarbonTracker-CH4: an assimilation system for estimating emissions of atmospheric methane. Atmos Chem Phys. 2014;14(16):8269-93. https://doi.org/10.5194/acp-14-8269-2014.

108. Patra PK, Saeki T, Dlugokencky EJ, Ishijima K, Umezawa T, Ito A, et al. Regional methane emission estimation based on observed atmospheric concentrations (2002-2012). J Meteorol Soc Jpn. 2016;94(1):91-113. https://doi.org/10.2151/jmsj.2016-006.

109. Houweling S, Krol M, Bergamaschi P, Frankenberg C, Dlugokencky EJ, Morino I, et al. A multi-year methane inversion using SCIAMACHY, accounting for systematic errors using TCCON measurements. Atmos Chem Phys. 2014;14(8):39914012. https://doi.org/10.5194/acp-14-3991-2014.

110. Banda N, Krol M, van Weele M, van Noije T, Rockmann T. Analysis of global methane changes after the 1991 Pinatubo volcanic eruption. Atmos Chem Phys. 2013;13(4):2267-81. https:// doi.org/10.5194/acp-13-2267-2013.

111. Zazzeri G, Lowry D, Fisher RE, France JL, Lanoiselle M, Kelly $\mathrm{BFJ}$, et al. Carbon isotopic signature of coal-derived methane emissions to the atmosphere: from coalification to alteration. Atmos Chem Phys. 2016;16(21):13669-80. https://doi.org/10. 5194/acp-16-13669-2016.

112. Ganesan AL, Stell AC, Gedney N, Comyn-Platt E, Hayman G, Rigby M, et al. Spatially resolved isotopic source signatures of wetland methane emissions. Geophys Res Lett. 2018;45(8): 3737-45. https://doi.org/10.1002/2018gl077536.

113. Fisher RE, France JL, Lowry D, Lanoiselle M, Brownlow R, Pyle $\mathrm{JA}$, et al. Measurement of the C-13 isotopic signature of methane emissions from northern European wetlands. Glob Biogeochem Cycles. 2017;31(3):605-23. https://doi.org/10.1002/2016gb005504 This study establishes a narrow isotopic signal for a regional source despite highly variable localised measurements.

114. Brownlow R, Lowry D, Fisher RE, France JL, Lanoiselle M, White $\mathrm{B}$, et al. Isotopic ratios of tropical methane emissions by atmospheric measurement. Glob Biogeochem Cycles. 2017;31(9): 1408-19. https://doi.org/10.1002/2017gb005689.

115. Rice AL, Butenhoff CL, Teama DG, Roger FH, Khalil MAK, Rasmussen RA. Atmospheric methane isotopic record favors fossil sources flat in 1980s and 1990s with recent increase. Proc Natl Acad Sci U S A. 2016;113(39):10791-6. https://doi.org/10.1073/ pnas. 1522923113.

116. Tyler SC, Brailsford GW, Yagi K, Minami K, Cicerone RJ. Seasonal variations in methane flux and $\delta^{13} \mathrm{CH}_{4}$ values for rice paddies in Japan and their implications. Glob Biogeochem Cycles. 1994;8(1):1-12.

117. Moller L, Sowers T, Bock M, Spahni R, Behrens M, Schmitt J, et al. Independent variations of $\mathrm{CH} 4$ emissions and isotopic composition over the past 160,000 years. Nat Geosci. 2013;6(10):88590. https://doi.org/10.1038/Ngeo1922.

118. McCalley CK, Woodcroft BJ, Hodgkins SB, Wehr RA, Kim EH, Mondav R, et al. Methane dynamics regulated by microbial community response to permafrost thaw. Nature. 2014;514(7523):478. https://doi.org/10.1038/nature13798.

119. Feinberg AI, Coulon A, Stenke A, Schwietzke S, Peter T. Isotopic source signatures: impact of regional variability on the delta(CH4)-C-13 trend and spatial distribution. Atmos Environ. 2018;174:99-111. https://doi.org/10.1016/j.atmosenv.2017.11. 037 This study examines the influence of source distribution on the $\delta^{13} \mathrm{CH}_{4}$ constraint.

120. Howarth RW. Ideas and perspectives: is shale gas a major driver of recent increase in global atmospheric methane? Biogeosciences. 2019;16:1-14. https://doi.org/10.5194/bg-16-1-2019.

121. Simpson IJ, Andersen MPS, Meinardi S, Bruhwiler L, Blake NJ, Helmig D, et al. Long-term decline of global atmospheric ethane concentrations and implications for methane. Nature. 2012;488(7412):490-4. https://doi.org/10.1038/Nature11342.

122. Mikaloff Fletcher S, Schaefer H. Rising methane: a new climate challenge. Science. 2019;364(6444):932-3. https://doi.org/10. 1126/science.aax 1828 .

Publisher's Note Springer Nature remains neutral with regard to jurisdictional claims in published maps and institutional affiliations. 